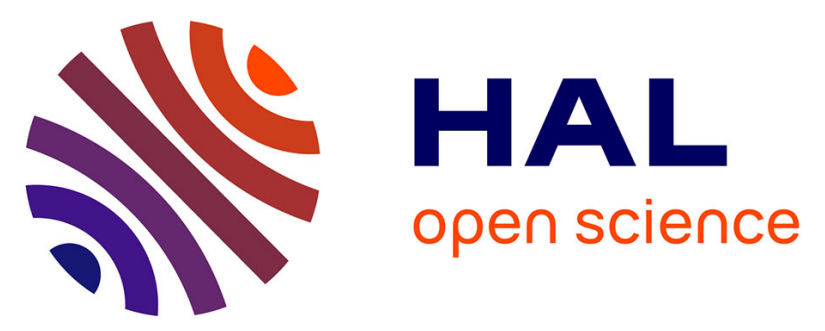

\title{
A review of RT-PCR technologies used in veterinary virology and disease control: sensitive and specific diagnosis of five livestock diseases notifiable to the World Organisation for Animal Health
}

Bernd Hoffmann, Martin Beer, Scott M. Reid, Peter Mertens, Chris A.L. Oura, Piet A. van Rijn, Marek J. Slomka, Jill Banks, Ian H. Brown, Dennis J. Alexander, et al.

\section{- To cite this version:}

Bernd Hoffmann, Martin Beer, Scott M. Reid, Peter Mertens, Chris A.L. Oura, et al.. A review of RTPCR technologies used in veterinary virology and disease control: sensitive and specific diagnosis of five livestock diseases notifiable to the World Organisation for Animal Health. Veterinary Microbiology, 2009, 139 (1-2), pp.1. 10.1016/j.vetmic.2009.04.034 . hal-00520658

\section{HAL Id: hal-00520658 https://hal.science/hal-00520658}

Submitted on 24 Sep 2010

HAL is a multi-disciplinary open access archive for the deposit and dissemination of scientific research documents, whether they are published or not. The documents may come from teaching and research institutions in France or abroad, or from public or private research centers.
L'archive ouverte pluridisciplinaire HAL, est destinée au dépôt et à la diffusion de documents scientifiques de niveau recherche, publiés ou non, émanant des établissements d'enseignement et de recherche français ou étrangers, des laboratoires publics ou privés. 


\section{Accepted Manuscript}

Title: A review of RT-PCR technologies used in veterinary virology and disease control: sensitive and specific diagnosis of five livestock diseases notifiable to the World Organisation for Animal Health

Authors: Bernd Hoffmann, Martin Beer, Scott M. Reid, Peter

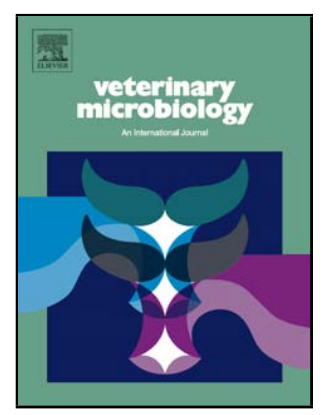
Mertens, Chris A.L. Oura, Piet A. van Rijn, Marek J. Slomka, Jill Banks, Ian H. Brown, Dennis J. Alexander, Donald P. King

PII: S0378-1135(09)00251-X

DOI: doi:10.1016/j.vetmic.2009.04.034

Reference: VETMIC 4435

To appear in: VETMIC

Received date:

$$
5-11-2008
$$

Revised date: $15-4-2009$

Accepted date: 28-4-2009

Please cite this article as: Hoffmann, B., Beer, M., Reid, S.M., Mertens, P., Oura, C.A.L., van Rijn, P.A., Slomka, M.J., Banks, J., Brown, I.H., Alexander, D.J., King, D.P., A review of RT-PCR technologies used in veterinary virology and disease control: sensitive and specific diagnosis of five livestock diseases notifiable to the World Organisation for Animal Health, Veterinary Microbiology (2008), doi:10.1016/j.vetmic.2009.04.034

This is a PDF file of an unedited manuscript that has been accepted for publication. As a service to our customers we are providing this early version of the manuscript. The manuscript will undergo copyediting, typesetting, and review of the resulting proof before it is published in its final form. Please note that during the production process errors may be discovered which could affect the content, and all legal disclaimers that apply to the journal pertain. 
1

\section{A review of RT-PCR technologies used in veterinary virology and} disease control: sensitive and specific diagnosis of five livestock diseases notifiable to the World Organisation for Animal Health

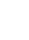

Bernd Hoffmann ${ }^{1}$, Martin Beer ${ }^{1 *}$, Scott M. Reid ${ }^{2}$, Peter Mertens ${ }^{2}$, Chris A. L. Oura ${ }^{2}$

Piet A. van Rijn ${ }^{3}$, Marek J. Slomka ${ }^{4}$, Jill Banks ${ }^{4}$, Ian H. Brown ${ }^{4}$, Dennis J.

Alexander ${ }^{4}$, Donald P. King ${ }^{2}$

${ }^{1}$ Institute of Diagnostic Virology, Friedrich-Loeffler-Institut, D-17493 GreifswaldInsel Riems, Germany

${ }^{2}$ Institute for Animal Health, Ash Road, Pirbright, Surrey. GU24 ONF, United Kingdom

${ }^{3}$ Central Veterinary Institute of Wageningen University Research Center (CVILelystad), P.O. Box 2004, 8203 AA Lelystad, The Netherlands

${ }^{4}$ OIE, FAO and EU Community Reference Laboratory (CRL) for Avian Influenza and Newcastle Disease, Virology Dept, Veterinary Laboratories Agency (VLA-

Weybridge), Addlestone, Surrey, KT15 3NB, United Kingdom

*corresponding author:

Dr. Martin Beer

Institute of Diagnostic Virology

Friedrich-Loeffler-Institut

Südufer 10

17493 Greifswald-Insel Riems

Tel. 0049-38351-7-200

Fax 0049-38351-7-275

e-mail: martin.beer@fli.bund.de 


\section{Abstract:}

35 Real-time, reverse transcription polymerase chain reaction (rRT-PCR) has become

36 one of the most widely used methods in the field of molecular diagnostics and

37 research. The potential of this format to provide sensitive, specific and swift detection

38 and quantification of viral RNAs has made it an indispensable tool for state-of-the-art

39 diagnostics of important human and animal viral pathogens. Integration of these

40 assays into automated liquid handling platforms for nucleic acid extraction increases

41 the rate and standardisation of sample throughput and decreases the potential for

42 cross-contamination. The reliability of these assays can be further enhanced by using

43 internal controls to validate test results. Based on these advantageous characteristics,

44 numerous robust rRT-PCRs systems have been developed and validated for important

45 epizootic diseases of livestock. Here, we review the rRT-PCR assays that have been

46 developed for the detection of five RNA viruses that cause diseases that are notifiable

47 to the World Organisation for Animal Health (OIE), namely: foot-and-mouth disease,

48 classical swine fever, bluetongue disease, avian influenza and Newcastle disease. The

49 performance of these tests for viral diagnostics and disease control and prospects for

50 improved strategies in the future are discussed.

53 Keywords: polymerase chain reaction; real-time PCR; FMDV; AIV; NDV; CSFV;

54 BTV 


\section{Real-time PCR technology}

Over the past decade, fluorescence-based polymerase chain reaction assays in realtime (real-time PCR) have become an established scientific tool for the detection of RNA, DNA and cDNA. This approach is a highly sensitive technique enabling simultaneous amplification and quantification of specific nucleic acid sequences. In addition to enhanced sensitivity, the benefits of real-time PCR assays over conventional endpoint detection methods include their large dynamic range, a reduced risk of cross-contamination, an ability to be scaled up for high throughput applications and the potential for accurate target quantification (Nazarenko et al., 1997; Schweiger et al., 2000; Black et al., 2002). Real-time PCR is suitable for a wide range of applications, such as gene expression analysis, determination of viral load, detection of genetically modified organisms, SNP (Single Nucleotide Polymorphisms) genotyping, and allelic discrimination. Detection of target sequences occurs by monitoring the fluorescence generated by intercalating dyes, fluorophore-labeled primers or sequence-specific probes. The use of a specific probe facilitates an increase in specificity compared to conventional agarose-gel based PCR assays (Bustin, 2000; Bustin et al., 2005). Quantification of target sequences is typically achieved by determining the number of amplification cycles required to generate PCR product (and corresponding fluorescence) at the beginning of the exponential phase of the PCR, in order to cross a threshold fluorescence line (threshold cycle $(\mathrm{Ct})=$ the number of cycles required to reach the threshold). In contrast with conventional PCR, where endpoint detection occurs in the plateau phase, preventing accurate quantification of nucleic acids, Ct values in real-time PCR correlate closely with the original quantity of target sequences.

\section{The development of multi-colour real-time PCR cyclers and "ready-to-use"} commercial multiplex real-time PCR kits has also made it possible to combine up to four assays within a single tube. Multiplex-PCR is the simultaneous amplification of two or more DNA (or cDNA) targets in a single reaction vessel and can only be carried out using uniquely-labelled probes for each target sequence. Typically, up to four target sequences can be detected in a multiplex 5' nuclease assay when the appropriate instrument and the right combination of fluorophores are used. Major advantages of multiplexing include a reduced sample requirement, which is especially important when sample material is scarce (Persson et al. 2005, Belak; 2007), and the 
91 ability to combine assays with an internal control system (Hoffmann et al., 2006). However, it is important to optimize these assays in order to limit competitive interactions that may significantly impact upon assay sensitivity.

The combined properties of high sensitivity and specificity, low contamination risk, and speed has made real-time PCR technology a highly attractive alternative to tissue culture- or immunoassay-based methods for diagnosing many infectious diseases (Espy et al., 2006). Clinical diagnostic applications and the use of real-time PCRs are growing exponentially, and real-time PCR is rapidly replacing conventional PCR and other established diagnostic methods such as antigen-ELISA and cell culture isolation. More general information is provided in a series of review articles (Mackay et al., 2002; Mackay, 2004; Bustin, 2000, 2002, 2005; Clementi et al., 1995; Niesters, 2002, 2004; Ratcliff et al., 2007; Gunson et al., 2006; Espy et al., 2006; Kaltenboeck and Wang, 2005; Kubista et al, 2006). This review considers the current scope and capability of this powerful technique, especially when detecting important notifiable viral pathogens of livestock such as foot-and-mouth disease virus (FMDV), classical swine fever virus (CSFV), bluetongue virus (BTV), avian influenza virus (AIV) and Newcastle disease virus (NDV).

\subsection{Detection formats}

\section{Detection formats without sequence confirmation of the PCR product}

113 Fluorescent dyes such as ethidium bromide (Higuchi et al., 1993; Wittwer et al.,

114 1997a; LePecq, 1966) that are specific for double-stranded DNA (dsDNA) were the

115 first systems employed in real-time PCR assays. Other intercalating dyes such as YO-

116 PRO-1 have also been used (Ishiguro et al., 1995; Tseng et al., 1997). SYBR Green I

117 is currently the most frequently used intercalating dye in real-time PCR. It has a 100

118 times higher binding affinity than ethidium bromide, and the fluorescence of bound

119 dye is more than 1000-fold higher than that of free dye. These properties make SYBR

120 Green I highly suitable for monitoring product accumulation during PCR (Wittwer et

121 al., 1997b; Morrison et al., 1998). An often-stated disadvantage of this format using

122 intercalating dyes, is that non-specific dsDNA products, such as primer dimers can

123 interfere with the assay signal and yield false positive results. Therefore, it is

124 important that the assay is optimized to avoid non-specific amplification products. 
125 Furthermore, melt curve analysis can be used to differentiate specific from nonspecific PCR products (Helps et al., 2002).

128 Another detection technology known as 'LUX (Light Upon eXtension)' utilizes a

129 modification to one of the two primers such that it possesses a fluorophore located

130 near the 3 'end in a hairpin structure (Nazarenko, 2006; Kusser, 2006).

131 The Amplifluor Quantitative PCR detection system uses a similar approach with

132 labelled and unlabelled primers (Nazarenko et al., 1997; Nuovo et al., 1999; Khripin,

133 2006). Both of these systems are described as highly flexible and beneficial, but have

134 not been frequently exploited for diagnostic tests.

\section{Detection formats with increased target specificity}

137 The incorporation of a specific probe into real-time PCR confirms the specificity of 138 the amplicon. Fluorophore-labelled oligonucleotide probes are most commonly used 139 for the specific detection of target sequences (Cardullo et al., 1988; Clegg, 1995; Wu 140 and Brand, 1994). In these assays, an increase in fluorescence signal proportional to 141 the accumulation of PCR product arises as a consequence of fluorescence resonance 142 energy transfer (FRET) between separate fluorogenic labels (known as the reporter 143 and quencher) conjugated to the probe (or primers). FRET, also called Förster

144 transfer, is a spectroscopic process by which energy is passed over a maximum 145 distance of $70 \AA$ between reporter and acceptor molecules possessing overlapping 146 emission and absorption spectra (Selvin and Hearst, 1994). For real-time PCR, several

147 formats have been used: however, most assays exploit a decrease in quench

148 (compared to an increase in FRET). The most commonly used fluorogenic quenchers 149 are TAMRA and DABCYL, while Black Hole Quencher (BHQ) is also widely used 150 and disperses energy from the reporter as heat rather than fluorescence (Didenko, 151 2001).

153 The most widely used detection chemistries are briefly reviewed below.

\section{Hybridisation probes}

156 Hybridisation probes, also known as 'HybProbes', use a pair of adjacent, fluorogenic

157 hybridisation oligos and are the only detection format that directly measures FRET

158 (Cardullo et al., 1988). These probes have become the preferred chemistry of the 
159

160

161

162

163

164

165

166

167

168

169

170

171

172

173

174

175

176

177

178

179

180

181

182

183

184

185

186

187

188

189

190

191

manufacturer for the capillary-based LightCycler system (Roche Molecular

Biochemicals; Wittwer et al., 1997a, 1997b) with special filters for the detection of the acceptor fluorophores Red 640 and Red 705.

\section{Hydrolysis probes (5'-exonuclease assay)}

Hydrolysis probes (commercially called TaqMan ${ }^{\circledR}$ probes) are dual-fluorophorelabelled oligonucleotides, with a 5'-terminal reporter (e.g. FAM) and a 3'-terminal quencher (e.g. TAMRA). Once the labels are separated by destroying the TaqMan $^{\circledR}$ probe based on the 5 -exonuclease activity of the DNA polymerase (e.g. Taq polymerase), the increase in reporter fluorescence caused by the removal of the adjacent quencher is monitored by a real-time PCR instrument (Heid, et al., 1996; Livak et al., 1995; Gibson, 1996). A modification of this strategy exploits the socalled minor groove binding (MGB) probes. MGB probes form extremely stable duplexes with single-stranded DNA targets mediated via van der Waals forces (Afonina et al., 2002): as a consequence shorter-length probes are required for hybridization. In comparison with unmodified DNA, MGB probes have higher $T_{\mathrm{m}}$ and are reported to hybridize with greater sequence specificity (Afonina et al., 1996;

Kutyavin et al., 2000). These short MGB probes are ideal for allele discrimination studies or for detection of single-nucleotide polymorphisms (SNPs) because they are more significantly destabilized by nucleotide changes within the hybridisation site compared with probes of longer length (de Kok et al., 2002; Belousov et al., 2004; Itabashi et al., 2004).

\section{Molecular beacons}

Molecular beacons are hairpin-shaped oligoprobes terminally labelled with a reporter and a quencher fluorophore (Tyagi and Kramer, 1996; Tyagi et al., 1998; Vet et al., 2002).

\section{Scorpion primer}

The Scorpion technology is mainly used in allelic discrimination (Whitcombe et al., 1999; Thelwel et al., 2000) and in SNP genotyping (Roberts, 2000).

\section{Locked nucleic acid (LNA) probes}


Incorporation of LNA residues increases the $T_{\mathrm{m}}$ of the oligonucleotide sequence, allowing the use of markedly shorter probes as allele-specific tools in genotyping assays (Costa et al., 2004; Latorra et al., 2003; Braasch and Corey, 2001).

\subsection{Internal controls}

The use of an internal control (IC) is an important aspect of quality control. An IC is necessary for ensuring adequate efficiency of RNA extraction and confirming the absence of PCR inhibitors in each sample, thereby avoiding false negative results (Belak and Thoren, 2001). An IC is a valuable tool when testing nucleic acids extracted from potentially difficult biological matrices (such as degraded samples) where the presence of PCR-inhibitors could be problematic. In these cases, coamplification of an IC increases the reliability of the results and is used to validate negative results. In practice, different IC systems can be used. One approach is to detect an endogenous gene that occurs naturally in the test specimen. To be a reliable indicator of assay performance, the gene selected should exhibit a constant, basal cell cycle-independent level of transcription that is not influenced by the cellular pathology associated with the disease targeted by the real-time assay in question.

Genes fulfilling these criteria are commonly known as housekeeping genes. Those used most often include glyceraldehydes-3-phosphate (GADPH), $\beta$-actin, $18 \mathrm{~S}$ ribosomal RNA, glutamate decarboxylase (GAD), and $\beta_{2}$-microglobulin (Oleksiewicz et al., 2001; Korimbocus et al., 2002; Gorzelniak et al., 2001; Hüssy et al., 2001; Kim and Dubovi, 2003; Huggett et al., 2005; Kompalic-Cristo et al., 2007; West et al., 2007; Müller et al., 2007; Toussaint et al., 2007). In contrast to an endogenous IC, an exogenous IC does not occur naturally within the nucleic acid preparation. This type of IC can be designed to contain an all-purpose heterologous target sequence (Hoffmann et al., 2006; Olson et al., 2004; Drosten et al., 2001) or a complete heterologous viral genome (Niesters, 2004; Stranska et al., 2004), unrelated to the sequence to be detected. To avoid apparent false-negative results, exogenous ICs can be added to each test sample before either the template purification step or prior to coamplification in the real-time PCR. Depending upon the particular design of these ICs, amplification of the control sequences may require that an additional set of primer pairs are included in the reaction. Alternatively, 'mimic' ICs (in-vitro transcripts, plasmids or chimeric viruses) can be engineered containing homologous target sequences for the same primer pair as the diagnostic test. In addition, these 
mimic ICs can contain internal sequences not present in the target amplicon to yield an amplification product with a different length (Belak and Thoren, 2001), which can be differentiated from wild-type amplicon by a second, IC-specific probe (King et al., 2003; Hofmann, 2003; Hodgson et al., 2007; Fedele et al., 2006; King et al., 2007).

Since these controls are amplified using the assay target-specific primers, a benefit of this type of control is that it directly monitors the performance of diagnostic primers set ensuring that the correct PCR components have been added. However, in contrast to the previously-described exogenous ICs, these target-specific control systems cannot be transferred to other assays, although a cassette approach can be designed to incorporate primer sequences of multiple diagnostic tests (King et al., 2007).

\subsection{Multiplexing}

In most cases the detection of co-amplified PCR products in one tube (multiplexing) were performed by hybridising probes and hydrolysis probes. Hybridising probes use the different melting points for differentiation of amplicons (Olson et al., 2004). On the other hand different emission spectra (colours) of sequence specific probes (TaqMan ${ }^{\circledR}$ or Hyb probes) allow also the detection of multiple sequences in a single reaction tube (Dupont et al., 2002; Wittwer et al., 2001). Some real-time PCR machines enable the detection and differentiation of up to 6 colours. This feature of real-time PCR becomes more and more important since it allows the cost-effective answer to several diagnostic questions within one sample in one reaction like agent detection together with sub-typing or the combined detection of several different pathogens (Gunson et al., 2008). Examples are established multiplex assays for the detection and sub-typing of influenza viruses (Wu et al., 2008; Payungporn et al., 2006) or the differentiation of Porcine circovirus-2 genotypes (Gagnon et al., 2008).

\subsection{Experiences of real-time PCR deployment in different laboratories}

A questionnaire campaign was conducted between the 19 collaborating partner institutes in Europe, Turkey and China that participate in an EU-funded research project for epizootic diseases "EPIZONE". Many of the participants are engaged in detection of the important pathogens of veterinary significance. Partners were asked about the strategies, techniques and equipment they utilise for performing real-time PCR. We will briefly summarise the findings of this survey before discussing specific information relating to the real-time PCR assays used for individual selected 
pathogens. Within the EPIZONE project, utilization of real-time PCR was widespread with many laboratories having a range of molecular tests in routine diagnostic use.

These assays included a broad assortment of the different detection chemistries (described above) and it is important to note that there are currently very few instances of assay harmonisation between the laboratories. All of the partners have at least one assay in the dual-labelled probe format (such as $\operatorname{TaqMan}^{\circledR}$ or MGB), while intercalating dyes were used by about $40 \%$ of the participants. About $10 \%$ also used alternative probe formats such as FRET probes (hybridization probes), molecular beacons or Primer-probe energy transfer (PriProET: to be described later) for some of their tests. Scorpion technology was not used. Nearly $90 \%$ of the participants undertake a one-step (RT and PCR in one reaction) rather than a two-step (separate RT and PCR step) strategy. Nearly half of the laboratories have internal controls, mostly endogenous housekeeping genes included in the assays which were incorporated as duplex targets in the tests.

\section{Detection of foot-and-mouth disease virus by rRT-PCR}

Foot-and-mouth disease (FMD) is a highly contagious disease affecting clovenhoofed livestock (cattle, sheep, pigs and goats). The causative agent is an RNA virus (FMDV: genus Aphthovirus, family Picornaviridae) with a positive sense genome approximately 8300 nucleotides in length. This virus exists as seven antigenically distinct serotypes (O, A, C, Asia 1, SAT 1, SAT 2 and SAT 3), as well as numerous and constantly evolving subtypes. FMD is endemic in large areas of Africa, Asia and South America and can readily cross international boundaries to cause epidemics in previously free areas. In disease-free countries, sporadic outbreaks of FMD can result in devastating losses to the agricultural industry due to the restrictions to international trade and the implementation of control measures to eradicate the disease. The significance of FMD as a major threat to the farming industry was dramatically illustrated during the 2001 FMD epidemic in the United Kingdom (UK). This outbreak lasted for 8 months requiring the slaughter of approximately 6.5 million animals for its control, and is estimated to have cost between $£ 2-8$ billion to the national economy. 
293 Control of outbreaks is dependent upon early recognition of infected animals, which

294 requires familiarity with clinical signs of FMD and the ability to accurately and

295 rapidly detect FMDV in clinical samples using laboratory tests. Of the established

296 diagnostic approaches, virus isolation (VI) in cell culture is considered to be the "gold

297 standard". This method can be highly sensitive (depending upon the cell culture

298 system used), although it can be slow taking between 1-4 days to generate a result.

299 Other assays such as antigen-detection ELISA are more rapid, but have lower

300 analytical sensitivity and are inappropriate for use with certain sample types. It is now

301 recognised that RT-PCR assays can play an important role for the rapid and sensitive

302 detection of FMDV in a wide range of clinical sample types. Over the past decade,

303 improvements have been made to RT-PCR protocols for the detection of FMDV that

304 have paralleled the evolution of molecular diagnostics. Initially, assays utilising

305 agarose-gel electrophoresis for the detection of amplified products and targeting

306 conserved regions of the genome (3D: Meyer et al., 1991; Rodríguez et al., 1994 and

307 5' untranslated region [5' UTR], Reid et al., 2000) were developed. However, these

308 labour intensive procedures have a high risk of generating false positives due to carry-

309 over of PCR amplicons and are therefore not ideal for routine testing of large numbers

310 of samples. Recent development of rRT-PCR methodology employing a

311 fluorescently-labelled probe to detect PCR amplicons has allowed the diagnostic

312 potential of molecular assays to be realised. These assays (outlined in Table 1) are

313 highly sensitive and obviate tube opening after amplification thereby reducing the

314 potential for cross-contamination of test samples by post-PCR products. In addition to

315 the widely exploited 5'-nuclease (TaqMan ${ }^{\circledR}$ ) system using dual-labelled probes (Reid

316 et al., 2002; Callahan et al., 2002; Oem et al., 2005) and modified MGB probes

317 (Mowika et al., 2007), assays have also been developed using other rRT-PCR formats

318 such as those using hybridisation probes (Moonen et al., 2003) and PriProET

319 (Rasmussen et al., 2003). In order to increase assay throughput and minimise operator

320 errors, rRT-PCR assays for FMDV can be automated using robots for nucleic acid

321 extraction and liquid handling equipment to set-up the reaction mixes (Reid et al.,

322 2003; Moonen et al., 2003). Together with the implementation of quality control

323 systems, these improvements have increased the acceptance of the rRT-PCR assays

324 for statutory diagnostic purposes. Although on-going studies continue this work, there

325 is already a wealth of data focusing on different aspects of validation to support the

326 use of rRT-PCR for routine FMD diagnosis: 
(i) evaluation of real-time assays with RNA prepared from different biological

329 matrices:

330 Vesicular epithelium is the sample of choice to collect from affected animals since it

331 is rich in virus during the acute phase of infection. In the absence of epithelium, blood

332 (collected during the acute phase), milk, oesophageal-pharyngeal scrapings

333 ('probangs') and mucosal swabs are suitable sample types for laboratory examination.

334 In addition to extensive testing of vesicular epithelium samples, the performance of

335 rRT-PCR has recently been assessed on milk (Reid et al., 2006) and "probang"

336 samples (Sammin et al., 2006).

(ii) comparison of rRT-PCR to other established diagnostic approaches

339 The performance of automated rRT-PCR has been compared with VI and antigen-

340 detection ELISA using samples submitted to the FAO/OIE Reference Laboratory

341 (Pirbright, UK). The results (Shaw et al., 2004) showed that all VI-positive samples

342 and those samples positive by VI and ELISA combined were also positive by rRT-

343 PCR. Depending on the rRT-PCR cut-off value used, FMDV genome was detected in

344 an additional $18 \%$ of samples tested. These findings indicate that the rRT-PCR has

345 higher sensitivity than VI for the detection of FMDV in epithelial samples. However,

346 in a subsequent study (Ferris et al., 2006), a number of VI-positive samples were

347 missed by a rRT-PCR detecting the 5' UTR. These assay failures were attributed to

348 nucleotide mismatches in the probe recognition region of a subset of related viruses

349 from the 2001 epidemic in the UK. This is a consequence of the high variability and

350 rapid mutation rate of the RNA genome of FMDV and highlights the importance of

351 constantly monitoring representative field FMDV strains by nucleotide sequencing to

352 ensure that the primers/probe set selected for the diagnostic rRT-PCR is fit for

353 purpose.

(iii) comparison of performance between different $r R T-P C R$ assays

356 An important aspect of these pan-serotype assays is that they target regions of the

357 FMDV genome which are conserved across the seven FMDV serotypes. The

358 nucleotide variability of six of these assays is shown in Figure 1. Nucleotide

359 substitutions in primer or probe recognition sites were also thought to underline

360 differences between the performance of rRT-PCR assays targeting the 5' UTR (Reid 
361 et al., 2002) and 3D region (Callahan et al., 2002). An initial study (Boyle et al., 2004)

362 using a small selection of inactivated viruses has recently been expanded to include a

363 more diverse selection of clinical samples from field cases of FMD (King et al.,

364 2006). There was concordance between the results generated by the two assays for the

365 majority of RNA samples extracted from epithelial tissue obtained from suspect FMD

366 cases. However, the comparison between the two tests highlighted a small number of

367 samples which failed to produce a signal in one assay while giving a positive signal in

368 the other. The sequence of the genomic targets for selected isolates highlighted

369 nucleotide substitutions in the primer and/or probe regions, thereby providing an

370 explanation for these negative results. Individually each rRT-PCR had higher

371 sensitivity than VI. However, the combined use of multiple and independent

372 diagnostic targets could further enhance the sensitivity of molecular methods for the

373 detection of FMDV.

(iv) inter-laboratory equivalence testing

376 Such is the diverse spectrum of approaches (Table 1) currently employed by different

377 National Reference Laboratories, it is unlikely that harmonisation of RT-PCR

378 protocols will be achieved in the short-term. To investigate inter-assay/laboratory

379 equivalence, five European reference laboratories participated in an exercise to

380 compare the sensitivity and specificity of their routinely-employed RT-PCR (and VI)

381 tests for detection of FMDV (Ferris et al., 2006b). The best of the RT-PCR assays

382 used in each laboratory gave comparable results (unlike the VI results which were

383 highly variable). A larger inter-laboratory comparison of RT-PCR methods involving

384 more than thirty laboratories is currently underway.

$386 \quad$ Future opportunities for RT-PCR diagnosis

387 During the 2001 epidemic, the UK government adopted a control strategy that

388 required slaughtering of animals on infected premises within 24 hours. In this

389 scenario, the time taken to transport material to a centralised laboratory was too long

390 to allow laboratory confirmation of suspect cases based on clinical signs. In order to

391 dramatically speed up the time taken for diagnosis, mobile or portable rRT-PCR

392 machines could potentially be used close to the suspect cases in the field, or in

393 regional laboratories. The desired characteristics of these assays are speed, sensitivity

394 and simplicity of use. With this in mind, the portable SmartCycler (Cepheid; Hearps 
et al., 2002; Callahan et al., 2002; Moniwa et al., 2007) and BioSeeq ${ }^{\mathrm{TM}}$ (Smiths

Detection; King et al., 2008) platforms have been evaluated for diagnosis of FMD.

The sensitivity and specificity of these assays were comparable to previously published real-time assays. However, further assay development and validation work is required in order that these assays will be suitable for detection of FMDV in field conditions. In particular, the development of simple-to-use and robust nucleic acid purification strategies is a priority, since the presence of tissue-derived factors may inhibit the RT-PCR and current extraction protocols are too complicated for field use. Isothermal amplification strategies (such as RT-loop-mediated isothermal amplification (LAMP) and nucleic acid sequence based amplification (NASBA)) offer an alternative to rRT-PCR which may be particularly appropriate for field-based assays since they are not reliant upon sophisticated instrumentation and have been reported to be less sensitive to tissue inhibitors. An RT-LAMP assay which has equivalent analytical sensitivity to rRT-PCR has been recently developed for FMDV (Dukes et al., 2006). This assay may form the basis of a highly sensitive, extremely rapid, specific, and cost-effective device for field diagnosis of FMD.

\section{Detection of Classical swine fever virus by rRT-PCR}

Classical swine fever (CSF) is a highly contagious and often fatal viral disease of pigs and wild boar. The causative agent of CSF, Classical Swine Fever Virus (CSFV), is a member of the genus Pestivirus within the family Flaviviridae (Fauquet et al., 2005). Further members within the genus Pestivirus are Bovine Viral Diarrhoea Virus (BVDV) and Border Disease Virus (BDV). CSFV is an enveloped virus with a 12.5 kb single-stranded RNA genome of positive sense (Horzinek, 1991). The genome consists of a single large open reading frame (ORF) which is flanked by highly conserved 5' and 3' non-translated regions (NTR) (Wirz et al., 1993; Boye et al., 1991). The ORF encodes a 4,000-amino acid polyprotein that is co- and posttranslationally processed by viral and cellular proteases into 12 polypeptides (Meyers et al., 1996). CSF causes major economic losses, especially in countries with an industrialized pig production system (Horst et al., 1999), and is therefore a disease notifiable to the Office International des Epizooties (OIE, 2006) and in the European 
Diagnosis of CSF comprises observation of clinical signs in the field, pathological findings and laboratory detection of the virus or virus-specific antibodies. Clinical and

431 pathological signs of CSF are rather variable and unspecific, and the severity of the

432 clinical signs depends on many factors, such as age of the animals, virulence,

433 presence of other pathogens or by host factors (Kaden et al., 2004, Floegel-Niesmann

434 et al., 2003; Mittelholzer et al., 2000; Depner et al., 1997; Kamolsiriprichaiporn et al., 435 1992a, 1992b). Therefore, laboratory diagnostics of CSF plays a central role in the 436 confirmation of an outbreak, and rapid and precise detection of CSFV is crucial for 437 disease containment. Besides the established virological methods, PCR techniques 438 have become increasingly important for CSF diagnostics during the last decade (Paton 439 et al., 2000), and PCR has been accepted by the European Union as an official method 440 for confirming this disease (Anonymous, 2002). Several rRT-PCR assays for CSF 441 diagnostics have been described (LePotier et al., 2006; Risatti et al., 2003, 2005; 442 Hoffmann et al., 2005; Uttenthal et al., 2003). The benefits of rRT-PCR are described 443 elsewhere in this review (Gibson et al., 1996; Wittwer et al., 2001; Mackay et al., 444 2002; Mackay, 2004). Depner at al. (2006, 2007) and Schnyder et al. (2002) have 445 highlighted the enhanced sensitivity and specificity of rRT-PCR for CSFV 446 confirmation over the conventional diagnostic methods, such as VI or antigen447 detection ELISA. Liu et al. (2007) compared conventional and rRT-PCR assays for 448 the sensitive and specific detection of CSFV. The authors demonstrated identical 449 sensitivities with these strategies but favoured the conventional, gel-based detection method for laboratories without facilities for rRT-PCR assays.

452 All published rRT-PCR assays for the detection of pestiviral sequences utilize the 5'

453 NTR (see Table 2) as target, and all those reported for specific detection of CSFV use 454 TaqMan $^{\circledR}$ probes with a specificity of $100 \%$. However, only four assays included an 455 IC to monitor RNA isolation, reverse transcription and amplification efficacy 456 (extraction and inhibition controls). Hoffmann et al. (2005) integrated an exogenous 457 IC serving both as an extraction and PCR inhibition control. Two commercially458 available assays amplify the cellular housekeeping gene GAPDH as an endogenous IC 459 (Le Dimna et al., 2006, 2007; Le Potier et al., 2006) while the housekeeping gene $\beta$ 460 actin was amplified in the assays described by Deng et al. (2005). 
462 Published quantitative rRT-PCRs have also been used to analyse the virus load in

463 blood and tissue samples collected from CSFV-infected pigs (Koenig et al., 2007;

464 Depner et al., 2006, 2007; Ophuis et al., 2006; Risatti et al., 2005, 2003; Uttenthal et

465 al., 2003). Uttenthal et al. (2003) used a SYBR Green assay for quantification but the

466 others favoured a TaqMan ${ }^{\circledR}$ format. Jamnikar Ciglenečki et al. (2008) compared a

467 SYBR Green assay with a TaqMan ${ }^{\circledR}$ MGB rRT-PCR for the detection of CSFV

468 genomes. While both assays were useful for CSFV detection, the TaqMan MGB

469 version was thought to be more appropriate based on a reduced risk of false positives

470 and the increased speed provided by the one-step format of the assay. Koenig et al.

471 (2007) also used a TaqMan ${ }^{\circledR}$ assay to investigate the distribution of a conventional C-

472 strain vaccine and a modified live marker vaccine candidate in pigs. The authors

473 demonstrated the rRT-PCR to be more sensitive than VI even though the viral

474 genomes of both vaccine strains were successfully detected in blood very rarely.

475 Long-term detection of CSFV genomes in tonsils was, however, shown in the same 476 study.

478 Ophuis et al. (2006) used specific primers and probes to detect the selected CSFV

479 strains NSW, Baker and Weybridge, for detailed pathogenesis studies. In this study,

480 CSFV was first detected in the tonsil (day 1), and subsequently in the submandibular

481 lymph node, spleen, ileum and mesenteric lymph node (by day 3 ). Thereafter, virus

482 spread to the visceral organs and finally to the pancreas and brain. These authors

483 concluded that tonsil samples, nasal and rectal swabs and whole blood samples were

484 the most favourable materials for rapid detection of CSFV using TaqMan ${ }^{\circledR}$-based

485 rRT-PCR assays.

486

487 For quick and cost-saving validation of techniques for molecular diagnostics,

488 quantification of genomes using real-time PCR assays has some key advantages:

489 Firstly, the sensitivity of different real-time PCR assays can be compared in one run

490 using a small number of identical templates; secondly, a real-time PCR assay can

491 quickly compare different genome extraction procedures. Deng et al. (2005) used

492 conventional and rRT-PCR assays to validate six RNA extraction kits for effective

493 detection of CSFV in blood and tissue samples, and concluded that all six methods

494 were more or less useful for the detection of CSFV by both assays in these samples

495 types. However, some of the methods offered certain advantages not common to all 
extraction procedures. For example, RNA extracted by the TRIzol LS reagent constantly had the highest yield, while the RNAqueous kit showed the highest A260/A280 ratio for almost all samples. Samples extracted using the NucleoSpin RNA II and the GenElute mammalian total RNA kits were demonstrated to be free of contamination with genomic DNA.

Modern real-time PCR cyclers can now measure up to 5 separate reporter fluorophores in one tube. This is a prerequisite for the application of multiplex realtime PCR assays. Beside the co-amplification of one target gene and an IC (Le Dimna et al., 2006, 2007; Le Potier et al., 2006, Hoffmann et al. 2005), different target genes can be detected in a single well (Wu et al., 2007; Legoff et al., 2008). Zho et al. (2008) as well as Leifer et al. (2009) developed a multiplex rRT-PCR assay for the simultaneous detection and differentiation of CSFV field strains and the C-strain vaccine virus.

The options provided by the current real-time PCR cylers, in combination with high quality commercial kits, should support the development of novel specific and highly sensitive multiplex rRT-PCR assays for the concurrent detection of several swine pathogens in the near future.

\section{Detection of Bluetongue virus by rRT-PCR}

Bluetongue disease (BT) is a non-contagious viral disease of domestic and wild ruminants that is transmitted by arthropod vectors of the genus Culicoides (Biting midges - reviewed by Mellor et al., 2000). Severe BT is primarily seen in sheep and in some species of deer, however significant levels of clinical disease were also seen in cattle during the recent bluetongue virus serotype 8 (BTV-8) outbreak in northern Europe. Bluetongue is endemic in many parts of the world including Africa and regions in the USA, Australia and Asia (Walton, 2004). Since 1998, multiple strains of BTV belonging to five different serotypes $(1,2,4,9$ and 16) have been circulating in more than 12 countries within the Mediterranean basin (reviewed by Purse et al., 2005), and in August 2006 a strain of BTV-8 was reported in The Netherlands, then soon afterwards in Belgium, Germany, France and Luxembourg. By October 2008 BTV-8 had spread into many more countries in Europe including the UK, 
530 Switzerland, Spain, Czeck Republic, Hungary, Denmark and Sweden. Also since

5312006 bluetongue virus serotype 1 (BTV-1) spread rapidly from North Africa through

532 Spain and into the south of France. These recent outbreaks of BT in northern Europe

533 have highlighted a need for rapid, high-throughput, sensitive and specific diagnostic

534 assays to detect and identify BTV.

536 The BTV genome consists of 10 segments of linear double-stranded RNA (dsRNA)

537 which encode 7 structural proteins (VP1-VP7) and 3 non-structural proteins (NS1,

538 NS2 and NS3/NS3A) (Mertens et al., 1984; Roy, 1989, Roy et al., 1990). There are 24

539 serotypes of BTV, determined by the specificity of interactions between neutralising

540 antibodies and the outer capsid of the virus, primarily with protein VP2 (encoded by

541 genome segment 2- the most variable region of the virus genome ). The remainder of

542 the BTV genome plays no significant part in determining virus serotype (with the

543 possible exception of genome segment 6 - encoding the other outer coat protein VP5).

544 The smallest genome segment (Seg-10) codes for a small non-structural membrane

545 protein NS3, and its truncated form NS3a, which also show a relatively high degree of

546 variability, although this is independent of virus serotype (Nikolakaki et al., 2005;

547 Balasuriya et al 2008). Genome segment 7 encodes the BTV core surface protein

548 VP7, which is also the major (immunodominant) bluetongue-serogroup specific

549 antigen. Perhaps surprisingly, Seg-7 also shows a relatively high degree of variability

550 across the bluetongue virus species as a whole (Bonneau et al 2000). In a recent study

551 of European BTV serotyopes it was detected as the third most variable region of the

552 virus genome (after Seg-2 and Seg-6) (Maan et al 2008). The majority of the other

553 BTV genome segments (which code for the virus core proteins or non-structural

554 proteins NS1 and NS2) are more highly conserved between BTV serotypes and

555 strains. However, significant variations are still detected in most of the BTV genome

556 segments (including segments 2 and 6), which reflect the geographical origins of the

557 virus, allowing isolates to be divided into different groups (e.g. 'east' and 'west') or

558 topotypes (Gould and Pritchard, 1990 Maan et al., 2007, 2008; Mertens et al., 2007;

559 Shaw et al., 2007; Anthony et al., 2007).

561 When designing primers for molecular assays it is important to select areas of the

562 BTV genome that are sufficiently conserved to enable the detection of all 24 serotypes 
563 and related topotypes, but also sufficiently divergent from sequences of the members

564 of other closely related Orbivirus species (other 'serogroups') to avoid cross-

565 reactions. The degree of variation detected within individual BTV genome segments

566 (e.g. between geographic groups) complicates the selection of appropriate targets.

567 However, several of the more conserved BTV genome segments have previously been

568 used as targets for molecular diagnostic methods, including: genome segment 5,

569 encoding the highly conserved non-structural 'tubule' protein NS1 (currently

570 recommended as an RT-PCR target by the OIE (OIE, 2008); genome segment 7

571 (despite its variability), encoding the BTV core surface protein and major BTV virus-

572 species / serogroup-specific antigen, VP7 (Gumm and Newman, 1982; Huismans,

573 1981; Mertens et al., 1987); genome segment 10 (encoding NS3/3a), in which

574 nucleotide variation between gene sequences of up to $20 \%$ have been detected (Pierce

575 et al., 1998; van Niekerk et al., 2003) and genome segment 1 encoding VP1, the viral

576 RNA-dependent RNA polymerase, one of the most highly conserved proteins of the

577 reoviruses (members of the family Reoviridae - Huang et al., 1995, Mertens, 2004).

578 Many of the conventional RT-PCR assays that have been developed are able to detect

579 BTV RNA in clinical samples (blood and spleen), including those targeting genome

580 segments 2, 3, 6, 7 and 10 (reviewed by Zientara et al., 2004), however, these

581 methods require agar gel electrophoresis to show the amplification of the target

582 sequence, which severely limits the speed of testing.

584 Prior to the BTV-8 outbreak in northern Europe in the summer of 2006, few real-time 585 PCR assays had been published for the detection of BTV. The first rRT-PCR assay 586 published for the detection of BTV, used primers designed from the NS1 gene (Seg-5)

587 (Wilson et al., 2004). However this assay detected only 11 out of the 19 serotypes 588 tested (serotypes 20-24 were not tested). The same year another rRT-PCR was 589 published using FRET-probe technology targeting genome segment 2 (VP2) (Orrù et 590 al., 2004, De Santis et al., 2004). This assay was used in Italy to differentiate wild591 type BTV-2 from the vaccine strain and was able to distinguish between vaccinated 592 and infected animals. In 2006 an rRT-PCR assay was developed using a conserved 593 region in RNA segment 5 of BTV-2 and BTV-4 (Jimenez-Clavero., 2006). This assay 594 detected all of the recent Mediterranean isolates that were tested (including isolates of 595 serotypes 2, 4 and 16), BTV vaccine strains for serotypes 2 and 4 and also 15 out of 596 the 24 BTV reference strains. The primers and probe were positioned in a part or 
segment 5 that had various mismatches which reduced the sensitivity of the assay.

Moreover, the assay was only able to detect field isolates, but not the reference strain, of BTV-4 and BTV-16 and in the recent northern European outbreak of BTV-8, this assay showed a reduced sensitivity for the detection of the field strain of BTV-8

601 compared to other assays (Batten et al., 2008a). Subsequent studies have indicated

602 that the field strain of BTV-16 from Italy 2002 that was tested was a reassortant virus,

603 containing genome segment 5 derived from a BTV-2 vaccine strain (Batten et al

604 2008b), potentially explaining differences in the sensitivity of the assay for field and

605 reference strains of this serotype. In the same year, a quantitative rRT-PCR was

606 developed using a Molecular Beacon (MB) fluorescent probe designed within the NS3

607 conserved region of segment 10 (Orrù et al., 2006). The MB is a circular

608 oligonucleotide characterised by a high specificity for the chosen target and by its

609 ability to develop a colour-forming reaction when used in a conventional RT-PCR

610 test. This assay successfully detected 10 serotypes (BTV-1, 2, 3, 4, 5, 6, 7, 8, 9, 16)

611 and detected $10^{3}$ molecules/PCR reaction.

612

613 Since the start of the northern European outbreak in August 2006 many rRT-PCR

614 assays have been developed, which are currently being used in many countries across

615 Europe. All the rRT-PCR assays that have been published up to 2008 are described in

616 Table 3. Some assays remain unpublished and, at the time of writing, 3 rRT-PCR

617 assays are published that are able to detect representative strains from all 24 serotypes

618 of BTV. Two of these assays were published in the same manuscript by Toussaint et

619 al., (2007). These two assays detect strains of the different BTV serotypes from the

620 Mediterranean region, as well as prototype strains of all 24 serotypes. Both assays

621 have similar detection limits of below $0.01 \mathrm{ECE}_{50}$ and detect $100 \mathrm{RNA}$ copies. The

622 primers were designed to target different genomic segments; a one-step procedure,

623 combining the reverse transcription (RT) and the PCR steps, to amplify BTV genome

624 segment 1 and a two-step procedure, with separate RT and PCR reactions, to amplify

625 genome segment 5. These assays have the advantage of a quantitative output which

626 gives an estimate of viral load and both assays include an internal beta-actin control

627 (Toussaint et al., 2007).

629 A further duplex rRT-PCR assay has been recently published by Shaw et al., (2007) in

630 which two sets of primers and probes were designed to target segment 1 of eastern 
631 and western group viruses respectively. This combined 'duplex' assay was evaluated using a wide variety of test samples, including tissue culture derived viruses, infected tissue and blood samples from cattle and sheep and infected Culicoides midges. This assay showed no cross-reactions with closely related orbiviruses and gave positive $\mathrm{Ct}$ results and amplification plots with all of the viruses tested, including a wide range of 129 different BTV isolates derived from different geographical locations (different topotypes), reference strains of all 24 BTV serotypes, and multiple field strains of BTV serotypes 1, 2, 4, 8, 9 and 16 from European outbreaks that have occurred since 1998, (although the BTV-9 vaccine and a Sicilian isolate of BTV-9 gave weaker but still positive responses). This assay was able to detect less than 10 template copies per reaction (equivalent to $0.5 \mathrm{TCID}_{50} / \mathrm{ml}$ in BHK21 cells). Differences in the sequences of Seg-1 also made it possible to use the two primer sets from the duplex assay, separately, to distinguish viruses of eastern and western origins.

A one step rRT-PCR method has also been described (Polci et al., 2007) that detects strains of BTV serotypes 2, 4, 9 and 16 isolated in Italy as well as their respective vaccine strains. The limit of detection of the assay fluctuated between 0.005 and 0.05 $\mathrm{TCID}_{50} / \mathrm{ml}$ depending on the virus strain. Preliminary tests also showed that this assay was able to identify serotype 1 , which was introduced into Italy towards the end of 2006, and also serotypes 8, 13,14 and 19 .

Given the high variability of BTV and the fact that real-time probes are very sensitive to probe-target mismatches (Jiminez-Clavero et al., 2006), it is important to emphasise that these assays may not be able to recognise all BTV strains and that the sensitivity of the assays may not be the same for every strain. It would thus be wise, as emphasised by Toussaint et al., (2007), to run two methods that amplify different genomic regions in parallel, as this would avoid the risk of missing a mutant, a recombinant or a reassortant strain. Results of PCR-based BTV diagnosis need to be interpreted with caution as BTV RNA has been detected in blood from both infected cattle and sheep for at least 30 days and sometimes up to 90 days after virus isolation

661 has ceased to be positive (Bonneau et al., 2002, Katz et al., 1993, MacLachlin et al.,

662 1994). Thus detection of virus-specific nucleic acid by these methods indicates a

663 recent virus infection, but does not necessarily indicate the presence of infectious 664 virus in the animal. 


\section{Detection of avian influenza virus by rRT-PCR}

667

668 Avian influenza viruses (AIV) belong to the genus Influenzavirus A, family

669 Orthomyxoviridae, possessing a negative stranded RNA genome of eight segments.

670 AIVs are classified into subtypes according to antigenic variation of the

671 glycoproteins, haemagglutinin $(\mathrm{H})$ and neuraminidase $(\mathrm{N})$, there are sixteen $\mathrm{H}$ types

672 and nine $\mathrm{N}$ types currently known. Wild birds, in which overt disease due to AI has

673 been rarely recorded, are the natural hosts for AIV and their migration is believed to

674 be important in its spread (Brown et al, 2006). Most AIV subtypes are termed low

675 pathogenicity avian influenzas (LPAIs) because little morbidity and mortality is

676 normally observed in infected chickens. LPAI virus infections are typically localised

677 to the avian respiratory and/or intestinal tract. However, H5 and H7 LPAI infections

678 in poultry may result in mutations in the viral haemagglutinin genes that bring about

679 changes at the HA0 "cleavage site" (CS, Figure 2) causing phenotypic change to

680 highly pathogenic avian influenza (HPAI) virus which spreads systemically. HPAI is

681 highly infectious to poultry and is characterised by rapid and aggressive spread of the

682 disease within a flock with very high mortality, typically within 48 hrs (Swayne \&

683 Suarez, 2000; OIE, 2005a). Both LPAI and HPAI poultry outbreaks caused by H5

684 and H7 AIVs are notifiable diseases (CEC, 2006; OIE, 2005b), and the biology of

685 such outbreaks and AIV wild bird isolates are under continuous scrutiny (Alexander,

686 2007; Senne, 2007).

687

688 HPAI is a constant threat to poultry in both developed and developing world

689 countries, especially in recent years as H5N1 HPAI virus originating in SE Asia

690 (Webster et al, 2006) spread westwards into Europe in late 2005 (FAO, 2006), and

691 into Africa in 2006 (Ducatez et al 2006). The risk of zoonotic AI infections in

692 humans also remains a concern for public health authorities (Alexander et al., 2005;

693 WHO Global Influenza Program Surveillance Network 2005; Chen et al 2006). In

694 terms of AI diagnosis, VI in embryonated fowls' eggs (EFEs) is the gold standard

695 method used followed by serological typing to identify the $\mathrm{H}$ and $\mathrm{N}$ subtypes by

696 haemagglutination inhibition (HI) and neuraminidase inhibition (NI) tests. Although

697 VI followed by HI and NI tests can take up to several days, these methods remain

698 obligatory to identify the index case of any new AI outbreak (OIE, 2005a; EU 2006). 
699 Clinical specimens appropriate for AI isolation include cloacal and oropharyngeal 700 swabs, ie from enteric and oral-respiratory shedding sites. Tissue specimens may also 701 be a source of AI, particularly from systemic HPAI infections, but for LPAI the virus 702 tends to be restricted to the respiratory and / or enteric tract.

704 It has been established that rRT-PCR provides rapidity, sensitivity and specificity for 705 diagnosis directly from clinical specimens. These are ideal qualities for AI outbreak 706 management, where prompt and unequivocal diagnosis may be crucial to decision 707 making by the relevant veterinary authority. Many real-time PCR platforms operate 708 in a 96-well format, and can be combined with high-throughput robotic RNA 709 extraction from specimens (Agüero et al., 2007). For AIV, this review will focus 710 primarily on TaqMan ${ }^{\circledR}$ (hydrolysis probe) approaches to rRT-PCR, and will 711 emphasise the importance of AI rRT-PCR validation. This is coupled to the 712 appropriate application of AI rRT-PCRs for poultry outbreaks and wild bird surveys 713 (WBSs). It is intended to provide the reader with guidelines for assessing any future 714 publications on AI rRT-PCR methodology. In this respect it is important to 715 distinguish genuine and practically relevant developments in AI diagnosis from 716 methods that may be scientifically interesting, but represent little or no practical 717 progress in AI diagnosis.

\section{Conventional AI RT-PCRs}

720 Laboratories have used conventional RT-PCR for AI characterisation since the 1990s, 721 but this involves initial biological amplification of AI specimens in EFEs in which 722 high AI titres $\left(e g 1 \times 10^{6} \mathrm{EID}_{50} / \mathrm{ml}\right.$ or greater) are obtained in the chorioallantoic fluid 723 (CAF) and used for RNA extraction. Sequencing of amplicons that span the region 724 coding for the HA0 CS region (Figure 2) may determine pathogenicity for $\mathrm{H} 5$ or $\mathrm{H} 7$ 725 AIVs (OIE, 2005a; EU 2006; Senne et al 2006). This has served as a very useful 726 adjunct to in vivo pathogenicity testing in poultry (Senne et al, 2006). Conventional 727 RT-PCR continues to be used to generate AIV sequence data, including 728 haemagglutinin gene sequences of $\mathrm{H} 5 / \mathrm{H} 7$ isolates from outbreaks (Bao et al, 2008).

729 This provides phylogenetic data to track the molecular epidemiology of AI outbreaks, 730 particularly if the variable HA1 region of the haemagglutinin gene (Figure 2) is 731 analysed (Banks et al, 2001). American H5 isolates are clearly phylogenetically 
732 distinct from Eurasian H5 isolates, and the same applies to American and Eurasian H7

733 isolates (Rohm et al, 1995).

735 However, there has been little regular use of conventional AI PCR in a diagnostic 736 setting where RNA has been directly extracted from clinical specimens. Swabs are 737 known to yield far lower AI titres than those in CAF harvests, particularly in the case 738 of LPAI infections (Wood et al, 1995). Ring trials conducted recently in the EU FP5 739 AVIFLU project identified H5 and H7 conventional RT-PCRs that can directly 740 amplify from extracted poultry specimens, at least from swabs containing high virus 741 titres obtained from HPAI infections (Figure 2, Slomka et al 2007a).

\section{M gene, H5 \& H7 testing by rRT-PCR}

M gene (generic) rRT-PCR:

746 The matrix (M) gene is highly conserved for all sixteen $\mathrm{H}$ subtypes from all geographical regions, and is an ideal target for global generic AIV detection (Figure 2). M gene rRT-PCR has been described and validated in testing clinical specimens obtained from live bird markets (LBMs) in the USA and from experimental infection studies (Spackman et al 2002; Lee \& Suarez 2004).

H5 and H7 specific rRT-PCRs:

753 The HA2 region has served as the target region for H5 and H7 TaqMan ${ }^{\circledR}$ rRT-PCRs as

754 it is relatively conserved within these respective haemagglutinin genes (Figure 2;

755 Spackman et al, 2002). These rRT-PCRs have also been shown to function efficiently 756 as H5 and H7 quantitative (Q)-rRT-PCRs in studies of virus shedding (Lee \& Suarez 757 2004). Spackman et al (2002) cautioned that their H5 and H7 primer / probe 758 sequences had been designed for the detection of North American H5 and H7 isolates 759 and were unlikely to be applicable to Eurasian viruses. The extent of sequence 760 divergence between viruses from the different hemispheres is so great that, even 761 within the HA2 region, it appears difficult to design a consistently sensitive rRT-PCR 762 for global detection of $\mathrm{H} 5$ or H7 AIVs. The primer and probe sequences of Spackman 763 et al (2002) were modified for detection of "Asian lineage" H5N1 AIV and also other 764 Eurasian H5 AIVs that have been isolated within the past decade (Figure 2; Slomka et 765 al, 2007b). This Eurasian H5 rRT-PCR has demonstrated its value in the investigation 
766 of many H5N1 HPAI clinical specimens submitted from Europe, Africa and Asia since autumn 2005 (Slomka et al 2007b). Monne et al (2008) have also described H5 and H7 rRT-PCRs that amplify within the HA2 region of Eurasian H5 and H7 AIVs

769 (Figure 2).

Eurasian H7 AIVs can also be detected by two validated H7 rRT-PCRs that target the

772 HA2 and the CS region (Slomka \& Voermans, 2007). Sequencing of the latter

773 amplicon provides molecular pathotyping data (Figure 2). Hoffmann et al. (2007)

774 described a H5 rRT-PCR in which the probe is included for the specific detection of

775 H5N1 HPAI. In this rRT-PCR the probe was carefully designed to bind to the

776 characteristic CS sequence of this particular H5 virus (Figure 2).

Validation of AI rRT-PCRs

779 Guidelines for validation of new molecular methods, in particular rRT-PCRs, have 780 been outlined by the OIE (OIE, 2004). Rigorous validation of AI rRT-PCRs requires 781 the following aspects to be addressed:

783 Sensitivity: the new method must successfully detect a range of different AI viruses.

784 Generic AI PCRs should detect representative isolates from among all sixteen $\mathrm{H}$ 785 subtypes. H5 and H7 rRT-PCRs should similarly detect a range of isolates among the 786 corresponding H subtype. While historic AI isolates may be available in many 787 laboratories, it is important to include contemporary AIVs from various geographic 788 locations. As mentioned above, it is also important to take into account genetic 789 diversity between Eastern and Western Hemisphere H5 and H7 subtype AIVs (Rohm 790 et al 1995). Furthermore, ongoing evaluation of 'fitness for purpose' has been done 791 using a large number of contemporary viruses and this will continue, especially 792 important given the highly mutable nature of the influenza virus genome.

794 Specificity: it must be shown that the new AI rRT-PCR does not produce false positive signals, e.g. testing of all non-H5 / H7 AIVs with H5 / H7 rRT-PCRs must

796 demonstrate clear specificity. Specificity testing should also include major non-AI 797 avian pathogens (especially Newcastle disease virus (NDV)) and a panel of clinical 798 specimens shown to be AI negative by VI. 
800

802

803

804

805

806

807

808

809

810

811

812

813

814

815

816

817

818

819

820

821

822

823

824

825

826

827

828

829

830

831

832

833

Testing of clinical specimens:

It is important to demonstrate that the new method is applicable to clinical materials.

Specimens should be tested by both the new AI rRT-PCR and VI in EFEs (ie the 'gold standard'). This will determine whether or not the new AI rRT-PCR is more sensitive than VI. Clinical specimens may be obtained from AI positive birds infected experimentally, during outbreaks or from wild birds.

The following studies describe AI rRT-PCRs which have included the above sample populations for validation: Spackman et al (2002) included extensive M gene rRTPCR testing on clinical specimens collected from LBMs in 2001. Comparative testing alongside VI revealed some discrepant results, which were discussed in detail (Spackman et al, 2002). Samples from poultry infected experimentally served to further validate the American H5/H7 type-specific assays (Lee \& Suarez, 2004). All three AI rRT-PCRs were shown to be generally more sensitive than VI (Spackman et al, 2002; Lee \& Suarez, 2004). Validation of the Eurasian H5 rRT-PCR included a wide range of Eurasian H5 AIVs (both LP and HP) and non-H5 AIVs (Slomka et al., 2007b). Clinical specimens were obtained from a number of suspect H5N1 HPAI submissions from Europe, Africa and Asia from autumn 2005 to spring 2006. It was concluded that the Eurasian H5 rRT-PCR is more sensitive than VI (Slomka et al. 2007b). Monne et al (2008) used a broad range of known AI isolates, plus large numbers of clinical specimens from poultry and wild birds to validate their sensitive and specific H5 and H7 rRT-PCRs in comparison with VI.

Few veterinary institutions possess substantial collections of AIVs or have access to clinical specimens that are key materials for such thorough validations. Lack of robust validation data will enevitably provide areas of uncertainty and result in such AI rRT-PCRs being classified as proposed or proof of principle methods.

\section{$\underline{\text { Use of AI rRT-PCRs in poultry outbreaks }}$}

Validated AI rRT-PCRs can bring great advantages to outbreak management and to decision making by the relevant veterinary authorities. AI rRT-PCR was used prospectively during the H7N2 LPAI poultry outbreak in Virginia, USA in 2002, in which 3,628 tracheal swabs were obtained (Akey, 2003). H7N2 LPAI was also detected by rRT-PCR in LBMs in 2002 and in commercial layers in 2003 (Swayne \& 
834 Akey, 2005). AI rRT-PCR demonstrated its value in these LPAI outbreaks where

835 clinical signs are not as dramatically clear as those observed in HPAI poultry

836 outbreaks.

838 During the HPAI poultry outbreak in British Columbia, Canada, in 2004, caused by a

839 virus of H7N3 subtype, swabs were tested initially by VI and M gene rRT-PCR, and

840 positives were tested by the American H7 rRT-PCR. M gene rRT-PCR was also used

841 for screening in the surveillance region that was established during the outbreak (Lees

842 et al, 2004; Pasick et al, 2007). Identification of likely progenitor H7N3 LPAI

843 isolates in poultry indicated the importance of accurate, sensitive and rapid laboratory

844 diagnosis.

845

846 Westward spread of H5N1 HPAI during the summer of 2005 (Chen et al 2005; Liu et 847 al 2005) accelerated EU emergency preparedness to tackle any subsequent European 848 outbreaks. This included recommendation of the M gene rRT-PCR (Spackman et al 849 2002) that had fared very effectively and reproducibly in blind testing of AI panels 850 organised within six EU laboratories (Slomka et al 2007a). Ongoing validation of the 851 Eurasian H5 rRT-PCR (Slomka et al 2007b) resulted in the inclusion of this method 852 among the EU recommended AI protocols (EU 2006). This contingency planning 853 was timely, with the first incursions of H5N1 HPAI in wild birds and/or poultry 854 occurring during autumn 2005 in Turkey, Romania, Croatia and Romania (FAO 2006; 855 Alexander 2007). These and subsequent European H5N1 reports in 2006 included a 856 high proportion of wild waterfowl cases, notably swans, and the Eurasian H5 rRT857 PCR demonstrated its value in the direct testing of clinical specimens (Slomka et al 858 2007b). European H5N1 HPAI outbreaks continue to be diagnosed by this method, 859 e.g. the three turkey outbreaks in the UK and Poland in 2007 (EU 2007).

861 The EU recommended H7 HA2 rRT-PCR (Slomka \& Voermans, 2007) has also 862 served in the diagnosis of LPAI poultry outbreaks caused by H7N3 (UK 2006;

863 Manvell et al., 2008), H7N2 (UK 2007; EU, 2007) and H7N1 (Denmark 2008; EU, 864 2008). An outbreak of H7N7 HPAI in chickens in the UK was diagnosed and 865 investigated in June 2008, where the H7 HA2 rRT-PCR again demonstrated its value 866 (Defra, 2008). 
868

869

870

871

872

873

874

875

876

877

878

879

880

881

882

883

884

885

886

887

888

889

890

891

892

893

894

895

896

897

898

899

900

901

\section{Wild bird surveys (WBSs) and AI rRT-PCR}

Recent years have seen renewed interest in AI WBSs, particularly to identify H5 and H7 AIVs (Munster et al 2005). M gene rRT-PCR has been used as the primary screening tool, with the inoculation of positive samples into EFEs for VI (Munster et al, 2005 \& 2006; Terregino et al, 2007). It has been observed consistently that VI is not $100 \%$ successful from all M gene rRT-PCR positive swabs (Terregino et al, 2007; Wallensten et al, 2007), inferring that a proportion of specimens contain detectable AI viral RNA that may not be infectious and recoverable in EFEs. This appears to be supported by high M gene rRT-PCR Ct values observed for these specimens, relating to very low AI titres (Slomka et al, unpublished). It is also possible that such WBS swabs may have their viability compromised during storage or transport. Such interpretation difficulties occur when $\mathrm{M}$ gene rRT-PCR results cannot be confirmed by VI nor conventional PCR, although in low titre specimens H5 and H7 subtypes may be confirmed by H5/H7 rRT-PCRs.

\section{Controls in AI rRT-PCR}

Van Borm et al. (2007) described the parallel use of $M$ gene and $\beta$-actin rRT-PCRs, in which the latter had been extensively validated for successful detection of avian $\beta$ actin RNA present in swabs and tissue specimens from forty-seven different bird species. Use of this endogenous internal control allows detection of false negatives in clinical specimens, or may resolve interpretation problems associated with high $\mathrm{Ct}$ value M gene rRT-PCR positives described above for WBSs by revealing sub-optimal levels of sampled specimen.

For use with the M gene rRT-PCR (Spackman et al 2002), Das et al. (2007) described an internal positive control (IPC) RNA, transcribed in vitro, which was carefully titrated and included without compromising the sensitivity of the M gene rRT-PCR.

The IPC possessed the same primer binding sequences as the M gene rRT-PCR, but a different probe binding sequence. This exogenous IPC detected PCR inhibitors in RNA extracted from blood, organs and cloacal swabs, but not in CAF, serum or tracheal swabs (Das et al 2007). Di Trani et al (2006) used a commercially available IPC for inclusion with a different M gene rRT-PCR (Figure 2).

\section{AI rRT-PCR Proficiency Testing}


902 Proficiency testing assesses competence for the practise of molecular diagnostic methods (OIE, 2002). In the EU, six AI National Reference Laboratories (NRLs)

904 were originally engaged in the AVIFLU project, where a programme of blind ring 905 trials was organised to identify sensitive and specific methods, which included $\mathrm{M}$ 906 gene (generic AI) rRT-PCR and H5/H7 conventional PCRs for molecular pathotyping 907 by amplicon sequencing (Slomka et al 2007a). As a result, EU AI PCR protocols for 908 inclusion in the Diagnostic Manual (EU 2006) were recommended and this trial 909 served as a template for the organisation of a larger annual pan-European AI PCR 910 proficiency testing panel for EU NRLs and other laboratories. This has been organised 911 since 2006 (Slomka 2006, 2007 \& 2008) with the aim of harmonising diagnostic AI 912 PCR approaches among veterinary laboratories across the EU, and included AI rRT-

913 PCRs for M gene and H5 and H7 subtype detection. These are now in use in twenty 914 seven NRLs in EU member states (Slomka 2008). Similar proficiency programmes 915 have also been introduced in the US (Suarez et al 2007).

917 In conclusion, this review has summarised the current published literature concerning 918 AIV rRT-PCR which are based on TaqMan ${ }^{\circledR}$ (hydrolysis probe) technology. The 919 importance of validation has been emphasised. The problem of evolving sequence 920 variability has been noted elsewhere in this review, and for AI high sequence 921 variability is observed in the haemagglutinin gene. Changes in primer or probe 922 binding sequences may affect the diagnostic sensitivity of a currently validated AI 923 rRT-PCR. Vigilance for future sequence changes in the Asian lineage H5N1 HPAI 924 (Smith et al., 2006) and other $\mathrm{H} 5 / \mathrm{H} 7$ genes is crucial, as modifications to protocols 925 may be necessary to restore optimal assay performance.

927 While validated AI rRT-PCRs have recently attained a very high standard of 928 diagnostic performance in terms of sensitivity and specificity, other molecular 929 methods will emerge within the coming years which may challenge the present 930 standing of AI rRT-PCRs. Regardless of the nature of any new molecular diagnostic 931 techniques, an appropriate and robust validation strategy will remain key for their 932 acceptance. 


\section{Detection of Newcastle disease virus by rRT-PCR}

938 Outbreaks of Newcastle disease (ND), caused by virulent Newcastle disease virus

939 (NDV), result in serious losses in poultry with an enormous economic impact. NDV is

940 an avian paramyxovirus with a single stranded negative sense RNA genome of

941 approximately 15.2 kilobases. NDV can differ in pathotype, defined as lentogenic,

942 mesogenic, and velogenic related to low, moderate, and high virulence, respectively.

943 The group of NDV represents one serotype (APMV-1) out of nine serotypes within

944 avian paramyxoviruses (APMV's). The NDV-group consists of at least six genetic

945 groups or genogroups. Recent analysis has revealed two distinct classes. (Czegledi et

946 al., 2006). Lentogenic strains are routinely used as vaccines. The diagnostic challenge

947 for ND is on the one hand the development of diagnostic tools differentiating between

948 vaccine strains and virulent NDVs, and on the other hand detecting all genetic groups 949 of NDV.

951 Suspicions of Newcastle disease cannot be conclusively diagnosed by clinical signs.

952 Many diseases, i.e. Fowl cholera, Avian influenza (HPAI), Laryngotracheitis, Fowl

953 pox (diphtheritic form), Ornithosis (psittacosis or chlamydiosis) (psittacine birds and

954 pigeons), Infectious bronchitis, Pacheco's parrot disease (psittacine birds), Gumboro

955 disease (very virulent strains), Salmonellosis (pigeons) show similar clinical signs or

956 one or more clinical signs that are also observed with ND. In addition, non-optimal

957 housing, i.e. withdrawal of water, air, or feed, or acute poisoning could result in

958 misdiagnosis of ND.

960 Conventional techniques, i.e. immunohistology (Hilbink et al., 1982),

961 immunoperoxidase-based methods (Lockaby et al., 1993), haemagglutination test,

962 inhibition test of haemagglutination using monospecific sera, and an in vitro test

963 detecting plaque formation in the absence of trypsin, are available. In addition, in vivo

964 tests are available to determine pathogenicity of NDV; intracerebral pathogenicity

965 index (ICPI) test, and mean death time in eggs (MDT). All these methods have one or

966 more disadvantages; they are laborious, expensive, use unacceptable numbers of

967 animals in experiments, and above all, are time-consuming delaying adequate control

968 measures after NDV-introduction. 
970 Plaque formation, as associated with virulence of NDV, appeared to be dependent on

971 additional basic amino acids at the processing site of the fusion protein. The detection

972 of codons for these basic amino acids is now accepted in place of in vivo and in vitro

973 tests for identification of virulent NDV (OIE, 2008). This, together with the fast

974 development of molecular diagnostic techniques, has stimulated many researchers to

975 develop new and fast methods to detect NDV and to identify virulent NDV in various

976 specimens.

977

978 In addition to RT-PCR methods, other molecular approaches, such as RT-LAMP, 979 have been recently developed for detection of NDV (Pham et al. 2005a). The big 980 advantage of all these molecular techniques is that isolation of infectious NDV, and

981 subsequent egg passage and/or cell line passages are not needed for diagnostic 982 purposes. Therefore, detection of genetic material specific for NDV directly from a 983 wide range of specimens, i.e. blood, faeces, tissues, and from different avian species 984 speeds up the diagnostic process significantly. Another advantage of molecular 985 techniques is the possibility of differential diagnosis by multiplex-RT-PCRs between 986 pathogens causing similar clinical signs, i.e. Avian influenza and ND (Farkas et al., 987 2007). RT-PCR can be achieved by universal primers that amplify targeted regions of 988 NDV, and thus detect its presence (Barbezange \& Jestin, 2002; Kant et al., 1997;

989 Gohm et al., 1999). However, even highly conserved genes like the M-gene shows 990 variability resulting in failures to detect NDV-isolates. A complementary assay based 991 on the L-gene has been developed to cover all NDVs, irrespective of virulence (Kim 992 et al., 2007). In contrast, many approaches have narrowed the specificity to virulent $993 \mathrm{NDV}$, and thus distinguish between virulent and vaccine strains. However, these 994 assays generally only detect a subset of all virulent NDVs, lacking the necessary 995 performance criteria for adoption into routine use.

997 Depending on the particular molecular method used, it is possible to detect, serotype, 998 and define the virulence of NDV in parallel. These integrated assay characteristics 999 speed up the diagnosis and characterisation of virulent NDV strains significantly.

1000 Detection of NDV by amplification of the region encoding the cleavage site of the 1001 fusion protein opens the possibility to identify the virulence by studying the presence 1002 of additional basic amino acid codons. Using open amplification systems, this has 1003 been achieved by several methods, i.e. subsequent sequencing of the amplicon (Gohm 
1004

1005

1006

1007

1008

1009

1010

1011

1012

1013

1014

1015

1016

1017

1018

1019

1020

1021

1022

1023

1024

1025

1026

1027

1028

1029

1030

1031

1032

1033

1034

1035

1036

1037

et al. 1999), a specific nested PCR (Barbezange and Jestin, 2002; Kant et al., 1997;

Kou et al., 1999; Kho et al., 2000), agarose-gel electrophoresis, or restriction enzyme analysis (Creelan and McCullough, 2006). A major risk of these approaches is contamination of samples by amplicon from previously amplified material during post-PCR manipulations.

NDV-specific rRT-PCR have utilised intercalating dyes such as SYBR-green (Tan et al. 2004). A drawback of this method is that amplification must be very specific as non-specific amplification contributes to the fluorescent signal. However, specificity of the amplicon can be checked afterwards by melt curve analysis and this approach has even been used for pathotyping (Pham et al. 2005b). Use of hybridization probes improved assay reliability: not only by offering a higher specificity, but also by raising the analytical sensitivity of detection of NDV-RNA, as approximately 10 EID $_{50}$ can be routinely detected by this method (Tan et al. 2004, Wise et al. 2004).

All these combinations of detection of virulent NDV by rRT-PCR have one major disadvantage; the targeted gene (F-gene) encoding the fusion protein is considerably variable. Since the primers used in the assay must be reliably amplify all virulent NDVs, it is diffcult (or perhaps impossible) to develop a single rRT-PCR to detect all virulent NDVs.. Alternatively, several RT-PCRs based on the F-gene can be performed in parallel or in the same tube to achieve amplification of the cleavage site of all NDVs. However, since this region is less conserved there will be a higher chance of failure for the amplification of new virus isolates. These concerns are also evident when considering the use of probes to detect products from these rRT-PCR reactions. The ability of a probe to hybridise to a specific product is very sensitive to mutations (Kim et al. 2006), however, this can be overcome by the use of many probes in one reaction (Aldous et al., 2001). Preferably a second RT-PCR based on a more conserved target, that detects all NDVs can be used to exclude false negative results by an F-gene based RT-PCR. However, such assays may still not cover all NDVs and so a second assay, based on L-gene may offer advantages since it will be applicable to most if not all strains (Kim et al., 2007). However, such assays targeting relatively conserved regions cannot be applied in vaccinated populations to diagnose ND, without recourse to tests leading to virulence determination. Published rRT-PCR assays used for NDV genome detection are listed in Table 4. 
1038 Reliability of laboratory diagnosis for ND is very important, since misdiagnosis has

1039

1040

1041

1042

1043

1044

1045

1046

1047

1048

1049

1050

1051

1052

1053

1054

1055

1056

1057

1058

1059

1060

1061

1062

1063

1064

1065

1066

1067

1068

1069

1070

1071 enormous consequences. In case of false negative results, a new outbreak remains undetected, and control measures are unnecessarily delayed. Therefore, frequent testing of rRT-PCR assays with new isolates to confirm sensitivity must be part of the sustainability of the laboratory diagnosis for ND. Concerning false positive results for $\mathrm{ND}$, the consequences could be even worse. In particular, the impact of a false positive index case in a ND-free country would be enormous. In addition to these diagnostic tests, it is important to sequence all (or part of) the F-gene of the isolate causing the outbreak for analysis of the cleavage site and epidemiological studies. It is always strongly recommended that virus is isolated from index cases to facilitate further analyses.

Nevertheless, after introduction of ND, high-throughput diagnostics is needed to control the outbreak. Focusing on molecular diagnostics for ND, in particular high throughput rRT-PCR diagnostics, only one report has been published using a validated 96-well format isolation- and rRT-PCR procedure (Crossley et al., 2005). Compared to VI, this assay had a diagnostic sensitivity of $100 \%$, and a diagnostic specificity of 95\% with excellent reproducibility. Many rRT-PCR assays have been published but are validated to a less rigorous extent. Most of these methods use manually extracted RNA or other isolation methods that are not amenable to automation. The particular benefits and disadvantages of these procedures must be taken into account and varies from use for vaccinated poultry to wild birds and from allantoic fluids to faeces. Application as a diagnostic tool in vaccinated poultry is limited to the assays based on a target on the F-gene, including the region encoding the cleavage site in order to be able to distinguish between vaccine and virulent strains (Kim et al., 2006). Application as a diagnostic tool for samples from sources such as different non-vaccinated avian species, including wild birds, is focused on more conserved regions such as the M-gene, although a second assay may be required to cover all NDVs (Kim et al., 2007).

In summary, molecular diagnostics for ND can essentially be divided into two categories depending on the purpose Detection of ND in avian species, and determination of virulent NDV. For detection of NDV, even if highly conserved targets like the M- and L-gene are chosen, it is very difficult to develop an rRT-PCR 
1072

1073

1074

1075

1076

1077

1078

1079

1080

1081

1082

1083

1084

1085

1086

1087

1088

1089

1090

1091

1092

1093

1094

1095

1096

1097

1098

1099

1100

1101

1102

1103

1104

1105

assay capable of detecting all NDVs (six genogroups to date). For characterisation and recognition of virulent NDV, part of the F-gene, including the region encoding the cleavage site, is the target of interest. However, it is extremely difficult to develop an assay to detect all virulent NDVs especially considering geographical variation.

The risk of false negatives due to variation in primer or probe locations is still a challenge to assay-developers. Nevertheless, it should be recommended that confirmatory assays be developed and utilised to avoid unnecessary delay of implementing control measures in case of a new outbreak. Only one extensive validation of a high-through PCR-based assay for ND has been published. In spite of recent progress, there is still a greater need for more reliable and improved validated rRT-PCR assays for the detection of NDV in general, as well as for identification of virulent strains of NDV.

\section{Discussion and general conclusions}

This review outlines the remarkable progress made over the past decade by real-time PCR techniques to improve pathogen detection for diagnostics and disease control. Beside the high sensitivity and ability to quantify viral targets, the substantial gain in specificity and the reduced risk of cross-contamination are important features of this technology. Integration of these assays onto automated high-throughput platforms provides diagnostic laboratories with the capability to test large numbers of samples that might be received during outbreaks of livestock disease. Although this review emphasises the positive features of rRT-PCR assays, it is important to recognise that there are a number of factors that can negatively impact upon the performance of these tests. In particular, the design of assays capable of detecting RNA viruses such as FMDV, CSFV, BTV, AIV and NDV with highly variably genomes can pose specific challenges. In addition to identifying conserved regions in the genome for primer-binding sites, the requirement to find further regions for the location of probe sites can reduce the diagnostic sensitivity of real-time PCR assay. In order to avoid this phenomenon, more than one real-time RT-PCR targeting different regions of the genome can be employed in parallel. As a consequence, the likelihood that mutations will cause failure of detection in both independent assays is very low (King et al., 2006). This "double check strategy" can be particularly important in the context of first line or exclusive diagnostics of pathogens using rRT-PCR. rRT-PCR assays can generate objective results regarding the presence of a particular pathogen in a sample. 
1106 However, border-line (or doubtful) results can arise when high Ct values below the cut-off of the test are generated. Unfortunately, non-PCR antigen detection methods are often not sensitive enough for a reliable independent confirmation of these signals.

1109 Therefore, a robust approach for dealing with these results should be adopted and

1110 standardised for each individual assay. It is recommended that an inconclusive

1111 interval (e.g. based on Ct-values or genome copies) is defined. Specimens with a

1112 doubtful result should be further analysed, e.g. using a second real-time PCR, a new

1113 extraction or a new sample from the same animal. In addition, for livestock

1114 investigations these effects can be mitigated or negated by the use of a robust

1115 statistically valid sampling frame at the level of epidemiological group. A further

1116 point to consider is putting in place systems to minimise the potential for cross-

1117 contamination. Although real-time PCR assays are closed tube, sub-optimal seals, the

1118 use and propagation of positive controls (e.g. plasmids, virus stocks), as well as

1119 further molecular procedures for the characterisation of detected genomes (e.g.

1120 sequencing) can cause false positive results in the test. In order to minimise cross-

1121 contamination, these different activities should be clearly separated away from the

1122 laboratory areas used to prepare nucleic acid template for the rRT-PCR.

1124 Modern real-time PCR cyclers can measure up to five separate reporter fluorophores

1125 in one tube. This technical feature is a prerequisite for the application of multiplex

1126 real-time PCR assays. Many of the rRT-PCR assays reviewed here co-amplified

1127 internal controls. It is recommended that these internal controls are included for each

1128 real-time PCR analysis. The minimum requirement for a state-of-the-art real-time

1129 PCR should be the use of an internal inhibition control in a duplex assay format. The

1130 currently published rRT-PCR assays for the detection of FMDV, CSFV, AIV, NDV

1131 and BTV summarized in this review are an excellent basis for the establishment of

1132 qualified and reliable molecular diagnostics. In Europe, these tests have recently

1133 provided critical support to the efficient control of notifiable diseases like FMD, AI,

1134 BT and CSF. Future work will continue to assess the performance of these assays,

1135 providing validation data for different sample types. Furthermore, continued inter-

1136 laboratory comparative exercises are also import to gauge the relative performance of

1137 tests used at different sites, and may ultimately lead to a more rational harmonisation

1138 of the rRT-PCR assays. 
1140 In conclusion, over the past decade rRT-PCR has become a central laboratory tool for

1141 the diagnosis of important livestock diseases. In light of the performance of these

1142 tests, it is evident that molecular diagnostics will be the main tool for eradication and

1143 control of epizootic diseases in the future.

1144

1145

Acknowledgements:

1146 This work was supported by the EU Network of Excellence, EPIZONE (Contract No

1147 FOOD-CT-2006-016236); UK Defra projects SE1121, SE1124, SE2613, SV3029,

1148 SV3033 and SV3400; BBSRC project BBS/Q/Q2004/05484, and EU supported Med

1149 Reo Net Project No.: 044285..

1150

1151

1152

1153

1154

1155

1156

1157

1158

1159

1160

1161

1162

1163

1164

1165

1166

1167

1168

1169

1170

1171

1172

1173 


\section{4}

1175

1176

1177

1178

1179

1180

1181

1182

1183

1184

1185

1186

1187

1188

1189

1190

1191

1192

1193

1194

1195

1196

1197

1198

1199

1200

1201

1202

1203

1204

1205

1206

1207

1208

1209

1210

1211

1212

1213

1214

1215

1216

\section{$\underline{\text { References }}$}

Afonina, I., Kutyavin, I., Lukhtanov, E., Meyer, R.B., Gamper, H. (1996) Sequencespecific arrest of primer extension on single-stranded DNA by an oligonucleotideminor groove binder conjugate. Proc Natl Acad Sci 93(8):3199-204.

Afonina, I.A., Reed, M.W., Lusby, E., Shishkina, I.G., Belousov, Y.S. (2002) Minor groove binder-conjugated DNA probes for quantitative DNA detection by hybridization-triggered fluorescence. Biotechniques 32(4):940-4, 946-9.

Anonymous. Council Directive 82/894/EEC of 21 December 1982 on the notification of animal diseases within the Community.Official Journal 1982;L 378:0058-62.

Anonymous, 2002. Commission decision 2002/106/EC of 1 February 2002 approving a diagnostic manual establishing diagnostic procedures, sampling methods and criteria for evaluation of the laboratory tests for the confirmation of classical swine fever

Anthony, S., Jones, H., Darpel, K. E., Elliott, H., Maan, S., Samuel, A. R., Mellor, P. S. \& Mertens, P. P. C. 2007. A duplex RT-PCR assay for detection of genome segment 7 (VP7 gene) from 24 BTV serotypes. J. Virol. Meth. 141, 188-197

Agüero, M., San Miguel, E., Sánchez, A., Gómez-Tejedor, C., Jiménez-Clavero, M.A., 2007. A fully automated procedure for the high-throughput detection of avian influenza virus by real-time reverse transcription-polymerase chain reaction. Avian Dis. $51,235-241$.

Akey, B. L., 2003. Low-pathogenicity H7N2 avian influenza outbreak in Virginia during 2002. Avian Dis. 47, 1099-1103.

Aldous EW, Fuller CM, Mynn JK, Alexander DJ. A molecular epidemiological investigation of isolates of the variant avian paramyxovirus type 1 virus (PPMV-1) responsible for the 1978 to present panzootic in pigeons. Avian Pathol. 2004 Apr;33(2):258-69.

Alexander, D.J., 2007. Summary of Avian Influenza Activity in Europe, Asia, Africa, and Australasia, 2002-2006. Avian Dis. 51, 161-166.

Alexander, D.J., Capua, I., Brown, I.H., 2005. Avian influenza viruses and influenza in humans. In: "Avian Influenza: Prevention and Control”, eds: Shrijver, R.S, Koch, G., pp1-8, Springer.

Balasuriya UB, Nadler SA, Wilson WC, Pritchard LI, Smythe AB, Savini G, Monaco F, De Santis P, Zhang N, Tabachnick WJ, Maclachlan NJ. (2008) The NS3 proteins of global strains of bluetongue virus evolve into regional topotypes through negative (purifying) selection. Vet Microbiol. 126, 91-100.

Banks, J., Speidel, E. S., Moore, E., Plowright, L., Piccirillo, A., Capua, I., Cordioli, P., Fioretti, A., Alexander, D. J., 2001. Changes in the haemagglutinin and the neuraminidase genes prior to the emergence of highly pathogenic $\mathrm{H} 7 \mathrm{~N} 1$ avian influenza viruses in Italy. Arch. Virol. 146, 963-973.

Barbezange C, and Jestin V. Development of a RT-nested PCR test detecting pigeon Paramyxovirus-1 directly from organs of infected animals. J Virol Methods. 2002 Dec;106(2):197-207.

Batten CA, Bachanek-Bankowska K, Bin-Tarif A, Kgosana L, Swain AJ, Corteyn M, Darpel K, Mellor PS, Elliott HG, Oura CAL, 2008a . Bluetongue virus: European 
1217 Community inter-laboratory comparison tests to evaluate ELISA and RT-PCR

1218 detection methods. Vet Microbiol. 129 (1-2): 80-8.

1219 Batten, C.A., Maan, S., Shaw, A.E., Maan, N.S., Mertens, P.P.C. 2008b A European

1220 field strain of bluetongue virus derived from two parental vaccine strains by genome

1221 segment reassortment. Virus Res. 137, 56-63.

1222 Bao, Y., Bolotov, P., Dernovoy, D., Kiryutin, B., Zaslavsky, L. Tatusova, T., Ostell,

1223 J., Lipman, D., 2008. The Influenza Virus Resource at the National Center for

1224 Biotechnology Information. J. Virol. 82, 596-601.

1225 http://www.ncbi.nlm.nih.gov/genomes/FLU/Database/select.cgi

1226 Belák S. Molecular diagnosis of viral diseases, present trends and future aspects A view from the OIE Collaborating Centre for the Application of Polymerase Chain Reaction Methods for Diagnosis of Viral Diseases in Veterinary Medicine.Vaccine. 2007 Jul 26;25(30):5444-52.

1230 Belak, S., Thoren, P. (2001) Molecular diagnosis of animal diseases: some

1231 experiences over the past decade. Expert Rev Mol Diagn 1(4):434-43.

1232 Belousov, Y.S., Welch, R.A., Sanders, S., Mills, A., Kulchenko, A., Dempcy, R.,

1233 Afonina, I.A., Walburger, D.K., Glaser, C.L., Yadavalli, S., Vermeulen, N.M.,

1234 Mahoney, W. (2004) Single nucleotide polymorphism genotyping by two colour

1235 melting curve analysis using the MGB Eclipse Probe System in challenging sequence

1236 environment. Hum Genomics 1(3):209-17.

1237 Black, E.M., Lowings, J.P., Smith, J., Heaton, P.R., McElhinney, L.M. (2002) A rapid

1238 RT-PCR method to differentiate six established genotypes of rabies and rabies-related

1239 viruses using TaqMan technology. J Virol Methods. 105(1):25-35.

1240 Bonneau, K.R., DeMaula, C.D., Mullens, B.A., MacLaughlan, N.J., (2002). Duration

1241 of viraemia infectious to Culicoides sonorensis in Bluetongue virus-infected cattle

1242 and sheep. Vet. Microbiol. 88, 115-125.

1243 Bonneau, K.R., Zhang, N.Z., Wilson, W.C., Zhu, J.B., Zhang, F.Q., Li, Z.H., Zhang,

1244 K.L., Xiao, L., Xiang, W.B., MacLchlan, N.J. (2000) Phylogenetic analysis of the S7

1245 gene does not segregate Chinese strains of bluetongue virus into a single topotype.

1246 Arch Virol.;145(6):1163-71.

1247 Boye, M., S. Kamstrup, and K. Dalsgaard. (1991). Specific sequence amplification of 1248 bovine virus diarrhea virus (BVDV) and hog cholera virus and sequencing of BVDV 1249 nucleic acid. Vet. Microbiol. 29:1-13.

1250 Boyle DB, Taylor T, Cardoso M. (2004) Implementation in Australia of molecular 1251 diagnostic techniques for the rapid detection of foot and mouth disease virus. Aust.

1252 Vet. J. 82, 421-425.

1253 Brown, I.H., Banks, J., Manvell, R.J., Essen, S.C., Shell, W., Slomka, M., Löndt, B., 1254 Alexander, D.J., (2006). Recent epidemiology and ecology of influenza A viruses in 1255 avian species in Europe and the Middle East. Dev. Biol., 124, 45-50.

1256 Bustin, S.A. (2000). Absolute quantification of mRNA using real-time reverse 1257 transcription polymerase chain reaction assays. J. Mol. Endocrinol. 25(2):169-93.

1258 Bustin, S.A.(2002). Quantification of mRNA using real-time reverse transcription 1259 PCR (RT-PCR): trends and problems. J. Mol. Endocrinol. 29: 23-39 
1260 Bustin, S.A., Benes, V., Nolan, T., Pfaffl, M.W. (2005) Quantitative real-time RT-

1261 PCR--a perspective. J Mol Endocrinol. 34(3):597-601.Anonymous. Council Directive

$126282 / 894 /$ EEC of 21 December 1982 on the notification of animal diseases within the

1263 Community.Official Journal 1982;L 378:0058-62.

1264 Callahan JD, Brown F, Osorio FA, Sur JH, Kramer E, Long GW, Lubroth J, Ellis SJ, 1265 Shoulars KS, Gaffney KL, Rock DL, Nelson WM. (2002) Use of a portable real-time 1266 reverse transcriptase-polymerase chain reaction assay for rapid detection of foot-and1267 mouth disease virus J Am Vet Med Assoc 220(11):1636-42

1268 Callens M, De Clercq K. (1997) Differentiation of the seven serotypes of foot-andmouth disease virus by reverse transcriptase polymerase chain reaction. J. Virol.

1270 Methods 67, 35-44.

1271 Cardullo, R.A., Agrawal, S., Flores, C., Zamecnik, P.C., Wolf, D.E. (1988) Detection 1272 of nucleic acid hybridization by nonradiative fluorescence resonance energy transfer.

1273 Proc Natl Acad Sci 85(23):8790-4.

1274 CEC, 2006. Council Directive 2005/94/EC of 20 December 2005 on Community

1275

1276

1277

1278

1279

1280

1281

1282

1283

1284

1285

1286

1287

1288

1289

1290

1291

1292

1293

1294

1295

1296

1297

1298

1299

1300

1301 Defra, National Emergency Epidemiology Group (NEEG), 2008. Highly Pathogenic 1302 measures for the control of avian influenza and repealing 92/40/EEC. Official Journal of European Commission, L10, 16-65.

Chen, H., Smith, G.J.D., Zhang, S.Y., Qin, K., Wang, J., Li, K.S., et al, 2005. Avian flu: H5N1 virus outbreak in migratory waterfowl. Nature 436, 191-192.

Chen, H., Smith, G.J.D., Li, K.S., Wang, J., Fan, X.H., Rayner, J.M., et al., 2006. Establishment of multiple sublineages of H5N1 influenza virus in Asia: implications for pandemic control. Proc. Natl. Acad. Sci. U S A 103, 2845-2850.

Clegg, R.M. (1995) Fluorescence resonance energy transfer. Curr Opin Biotechnol 6(1):103-10.

Clementi M, Menzo S, Manzin A, Bagnarelli P. Quantitative molecular methods in virology. Arch Virol. 1995;140(9):1523-39. Review.

Costa JM, Ernault P, Olivi M, Gaillon T, Arar K. (2004) Chimeric LNA/DNA probes as a detection system for real-time PCR. Clin Biochem. Oct;37(10):930-2.

Crossley BM, Hietala SK, Shih LM, Lee L, Skowronski EW, Ardans AA. Highthroughput real-time RT-PCR assay to detect the exotic Newcastle Disease Virus during the California 2002--2003 outbreak. J Vet Diagn Invest. 2005 Mar;17:124-32.

Creelan JL, McCullough SJ. Detection and differentiation of pathogenicity of avian paramyxovirus serotype 1 (APMV-1) from field cases using one-step real-time RTPCR. Dev Biol (Basel). 2006;126:149-57; discussion 325-6.

Czeglédi A, Ujvári D, Somogyi E, Wehmann E, Werner O, Lomniczi B. Third genome size category of avian paramyxovirus serotype 1 (Newcastle disease virus) and evolutionary implications. Virus Res. 2006 Sep;120(1-2):36-48.

Das, A., Spackman, E., Senne, D., Pedersen, J., Suarez, D.L., 2006. Development of an internal positive control for rapid diagnosis of avian influenza virus infections by real-time reverse transcription-PCR with lyophilized reagents. J. Clin. Microbiol. 44, 3065-3073.

Avian Influenza H7N7, Oxfordshire, June 2008. 
1303

1304

1305

1306

1307

1308

1309

1310

1311

1312

1313

1314

1315

1316

1317

1318

1319

1320

1321

1322

1323

1324

1325

1326

1327

1328

1329

1330

1331

1332

1333

1334

1335

1336

1337

1338

1339

1340

1341

1342

1343

1344

1345

http://www.defra.gov.uk/animalh/diseases/notifiable/disease/ai/latestsituation/index.htm

de Kok, J.B., Wiegerinck, ET., Giesendorf, B.A., Swinkels, D.W. (2002) Rapid genotyping of single nucleotide polymorphisms using novel minor groove binding DNA oligonucleotides (MGB probes). Hum Mutat 19(5):554-9.

Deng MY, Wang H, Ward GB, Beckham TR, McKenna TS. Comparison of six RNA extraction methods for the detection of classical swine fever virus by real-time and conventional reverse transcription-PCR. J Vet Diagn Invest. 2005 Nov;17(6):574-8.

Depner, K.R., Greiser-Wilke, I., Moennig, V., Liess, B. (1997) Breed dependent variations influence the outcome of classical swine fever virus infection in pigs. In: Edwards S, Paton DJ, Wenswoort G, editors. Proceedings of the third ESVV symposium on pestivirus infections. p. 59-61.

Depner, K., Bunzenthal, C., Heun-Münch, B., Strebelow, G., Hoffmann, B., Beer, M. (2006) Diagnostic evaluation of a real-time RT-PCR assay for routine diagnosis of classical swine fever in wild boar. J. Vet. Med. B 53, 317-320.

Depner, K., Hoffmann, B., Beer, M. (2007) Evaluation of real-time RT-PCR assay for the routine intra vitam diagnosis of classical swine fever Veterinary Microbiology 121: 338-343.

De Santis, P., Orru, G., Solinas, F., Piras, V., Savini, G., Caporale, V., 2004.

Molecular differentiation of field and vaccine strains of bluetongue virus serotype 2 using the real-time polymerase chain reaction and fluorescene resonance energy transfer hybridisation probe, Vet Ital. 40, 572-576.

Didenko, V.V. (2001) DNA probes using fluorescence resonance energy transfer (FRET): designs and applications. Biotechniques 31(5):1106-16, 1118, 1120-1.

Di Trani, L., Bedini, B., Donatelli, I., Campitelli, L., Chiappini, B., De Marco, M.A., Delogu, M., Buonavoglia, C., Vaccari, G., 2006. A sensitive one-step real-time PCR for detection of avian influenza viruses using a MGB probe and an internal positive control. BMC Infect. Dis. 6, 87.

Drosten, C., Seifried, E., Roth, W.K. ( 2001) TaqMan 5'-nuclease human immunodeficiency virus type 1 PCR assay with phage-packaged competitive internal control for high-throughput blood donor screening. J Clin Microbiol 39(12):4302-8

Ducatez, M.F., Olinger, C.M., Owoade, A.A., de Landtsheer, S., Ammerlaan, W., Niesters, H.G., et al 2006. Avian flu: multiple introductions of H5N1 in Nigeria. Nature 442, 37.

Dukes JP, King DP, Alexandersen S. (2006) Novel reverse transcription loopmediated isothermal amplification for rapid detection of foot-and-mouth disease virus. Arch. Virol. 151(6), 1093-1106.Braasch, D.A., Corey, D.R. (2001) Locked nucleic acid (LNA): fine-tuning the recognition of DNA and RNA. Chem Biol 8(1):1-7.

Dupont, M., Goldsborough, A., Levayer, T., Savare, J., Rey, J.M., Rossi, J.F., Demaille, J., Lavabre-Bertrand, T. (2002) Multiplex fluorescent RT-PCR to quantify leukemic fusion transcripts. Biotechniques 33(1):158-60, 162, 164.

Espy MJ, Uhl JR, Sloan LM, Buckwalter SP, Jones MF, Vetter EA, Yao JD, Wengenack NL, Rosenblatt JE, Cockerill FR 3rd, Smith TF. (2006) Real-time PCR in 
1346 clinical microbiology: applications for routine laboratory testing. Clin Microbiol Rev. Jan;19(1):165-256

1348 EU, 2006. Diagnostic manual for avian influenza. http://eur-

1349 lex.europa.eu/LexUriServ/site/en/oj/2006/1_237/1_23720060831en00010027.pdf

1350 EU, 2007. Avian influenza (AI): Extensive chronology of main events and list of

1351 decisions adopted by the European Commission in 2007.

1352 http://ec.europa.eu/food/animal/diseases/controlmeasures/avian/31-12-

$1353 \quad 2007$ ai_chronology.pdf

1354 EU, 2008. Low pathogenic avian influenza H7N1 in Denmark.

http://ec.europa.eu/food/committees/regulatory/scfcah/animal health/presentations/ai 78052008 dk.pdf

FAO, 2006. Evolution of highly pathogenic avian influenza type H5N1 in Europe: review of disease ecology, trends and prospects of spread in autumn-winter 2006. In: "Empres Watch. Emergency prevention systems", October 2006. http://www.fao.org/docs/eims/upload/214878/EW_europe_oct06 hpai.pdf

Farkas T, Antal M, Sámi L, Germán P, Kecskeméti S, Kardos G, Belák S, Kiss I. Rapid and simultaneous detection of avian influenza and newcastle disease viruses by duplex polymerase chain reaction assay. Zoonoses Public Health. 2007;54(1):38-43. Virus Taxonomy, VIIIth Report of the ICTV. London: Elsevier/Academic Press.

Fedele, C.G., Negredo, A., Molero, F., Sanchez-Seco, M.P., Tenori, A. (2006) Use of internally controlled real-time genome amplification for detection of variola virus and other orthopoxviruses infecting humans. J Clin Microbiol. 44(12):4464-70.

Ferris NP, Dawson M. (1988) Routine application of enzyme-linked immunosorbent assay in comparison with complement fixation for the diagnosis of foot-and-mouth and swine vesicular diseases. Vet. Microbiol. 16, 201-209. Ferris NP, King DP, Reid SM, Shaw AE, Hutchings GH. (2006a) Comparisons of original laboratory results and retrospective analysis by real-time reverse transcriptase-PCR of virological samples collected from confirmed cases of foot-andmouth disease in the UK in 2001. Vet. Rec. 16;159(12):373-8.

1378 Ferris NP, King DP, Reid SM, Hutchings GH, Shaw AE, Paton DJ, Goris N, Haas B, Hoffmann B, Brocchi E, Bugnetti M, Dekker A, De Clercq K. (2006b) Foot-andmouth disease virus: a first inter-laboratory comparison trial to evaluate virus isolation and RT-PCR detection methods. Vet. Microbiol. 117(2-4), 130-140. recent and former classical swine fever virus isolates evaluated by their clinical and pathological signs. J. Vet. Med B, 50:214-20. (2008). Development and use of a multiplex real-time quantitative polymerase chain reaction assay for detection and differentiation of Porcine circovirus-2 genotypes $2 \mathrm{a}$ and $2 \mathrm{~b}$ in an epidemiological survey. J. Vet. Diagn. Invest., 20:545-58.

1389 Gibson, U.E., Heid, C.A., Williams, P.M. (1996) A novel method for real time 1390 quantitative RT-PCR. Genome Res 6(10):995-1001. 
1391 Gohm D, Schelling E, Audigé L, Thür B. (1999). Newcastle disease--

1392

1393

1394

1395

1396

1397

1398

1399

1400

1401

1402

1403

1404

1405

1406

1407

1408

1409

1410

1411

1412

1413

1414

1415

1416

1417

1418

1419

1420

1421

1422

1423

1424

1425

1426

1427

1428

1429

1430

1431

1432

1433

1434

seroepidemiologic study of a highly contagious epizootic in poultry and in wild birds in Switzerland Schweiz Arch Tierheilkd.141:549-58. German. J Vet Med Sci. 1999 Nov;61(11):1191-5.

Gorzelniak, K., Janke, J., Engeli, S., Sharma, A.M. (2001). Validation of endogenous controls for gene expression studies in human adipocytes and preadipocytes. Horm Metab Res 33(10):625-7

Gould, A.R., Pritchard, L.I., 1990. Relationships amongst bluetongue viruses revealed by comparisons of capsid and outer coat protein nucleotide sequences. Virus Res. 17, $31-52$.

Gumm, I.D., Newman, J.F., 1982. The preparation of purified bluetongue virus group antigen for use a as a diagnostic reagent. Arch. Virol. 72, 83-93.

Gunson RN, Collins TC, Carman WF. Practical experience of high throughput real time PCR in the routine diagnostic virology setting. J Clin Virol. 2006 Apr;35(4):35567.

Gunson, R., Bennett, S., Maclean, A., Carman, W. (2008) Using multiplex real time PCR in order to streamline a routine diagnostic service. Journal of Clinical Virology, 43: $372-375$

Heid, C.A., Stevens, J., Livak, K.J., Williams, P.M. (1996) Real time quantitative PCR. Genome Res 6(10):986-94.

Helps, C., Lait, P., Tasker, S., Harbour, D. (2002) Melting curve analysis of feline calicivirus isolates detected by real-time reverse transcription PCR. J Virol Methods. 106(2):241-4.

Hearps A, Zhang Z, Alexandersen S. (2002) Evaluation of the portable Cepheid SmartCycler real-time PCR machine for the rapid diagnosis of foot-and-mouth disease. Vet Record 150, 625-628.

Higuchi, R., Fockler, C., Dollinger, G., Watson, R. (1993) Kinetic PCR analysis: realtime monitoring of DNA amplification reactions. Biotechnology 11(9):1026-30.

Hilbink F, Vertommen M, Tibben J, van't Veer W. The fluorescent antibody technique in the diagnosis of a number of poultry diseases: manufacture of conjugates and use (author's transl) Tijdschr Diergeneeskd. 1982 Mar 1;107(5):167-73.

Hodgson, J., Zuckerman, M., Smith, M. (2007) Development of a novel internal control for a real-time PCR for HSV DNA types 1 and 2. J Clin Virol. 38(3):217-20.

Hoffmann, B., Depner, K., Schirrmeier, H., Beer, M. (2006) A universal heterologous internal control system for duplex real-time RT-PCR assays used in a detection system for pestiviruses. J Virol Methods 136(1-2):200-9.

Hoffmann, B., Beer, M., Schelp, C., Schirrmeier, H., Depner, K. (2005) Validation of a real-time RT-PCR assay for sensitive and specific detection of classical swine fever. J. Virol. Methods 130, 36-44.

Hoffmann, B., Harder, T., Starick, E., Depner, K., Werner, O., Beer, M., 2007. Rapid and highly sensitive pathotyping of avian iInfluenza A H5N1 virus by using real-time reverse transcription-PCR. J. Clin. Microbiol. 45, 600-603.

Hofmann, M.A. (2003) Construction of an infectious chimeric classical swine fever virus containing the 5'UTR of bovine viral diarrhea virus, and its application as a 
1435

1436

1437

1438

1439

1440

1441

1442

1443

1444

1445

1446

1447

1448

1449

1450

1451

1452

1453

1454

1455

1456

1457

1458

1459

1460

1461

1462

1463

1464

1465

1466

1467

1468

1469

1470

1471

1472

1473

1474

1475

1476

universal internal positive control in real-time RT-PCR. J Virol Methods 114(1):7790.

Horst, H.S., Meuwissen, M.P.M., Smak, J.A., Van de Meijs, C.C.J.M., 1999. The involvement of the agriculture industry and government in animal disease emergencies and the funding of compensation in Western Europe. Rev. Sci. Tech. Off. Int. Epiz. 18, 30-37.

Horzinek, M. C. 1991. Pestiviruses - taxonomic perspectives. Arch. Virol. Suppl. $3: 1-5$.

Huang, I.J., Hwang, G.Y., Yang, Y.Y., Hayama, E. and Li, J.K., 1995. Sequence analyses and antigenic epitope mapping of the putative RNA-directed RNA polymerase of five U.S. bluetongue viruses. Virology 214, 280-8.

Huismans, H.a.E., B.J., 1981. Identification of the seroype-specific and group specific antigens of Bluetongue virus. Ond. J. Vet. Res. 48, 51-58.

Hüssy, D., Stauber, N., Leutenegger, C.M., Rieder, S., Ackermann, M. (2001)

Quantitative fluorogenic PCR assay for measuring ovine herpesvirus 2 replication in sheep. Clin. Diagn. Lab. Immunol. 8, 123- 128.

Huggett, J., Dheda, K., Bustin, S., Zumla, A. (2005) Real-time RT-PCR normalisation; strategies and considerations. Genes Immun 6(4):279-84

Ishiguro, T., Saitoh, J., Yawata, H., Yamagishi, H., Iwasaki, S., Mitoma, Y. (1995) Homogeneous quantitative assay of hepatitis $\mathrm{C}$ virus RNA by polymerase chain reaction in the presence of a fluorescent intercalater. Anal Biochem 229(2):207-13.

Itabashi, T., Maesawa, C., Uchiyama, M., Higuchi, T., Masuda, T. (2004)

Quantitative detection of mutant alleles of the K-ras gene with minor groove binderconjugated fluorogenic DNA probes. Int J Oncol 24(3):687-96.

Jamnikar Ciglenečki U, Grom J, Toplak I, Jemeršić L, Barlič-Maganja D. Real-time RT-PCR assay for rapid and specific detection of classical swine fever virus:

Comparison of SYBR Green and TaqMan MGB detection methods using novel MGB probes. J Virol Methods. 2008 Feb;147(2):257-64

Jimenez-Clavero, M.A., Aguero, M., San Miguel, E., Mayoral, T., Lopez, M.C., Ruano, M.J., Romero, E., Monaco, F., Polci, A., Savini, G. and Gomez-Tejedor, C., 2006. High throughput detection of bluetongue virus by a new real-time fluorogenic reverse transcription-polymerase chain reaction: application on clinical samples from current Mediterranean outbreaks. J Vet Diagn Invest 18, 7-17.

Kaden, V., Lange, E., Polster, U., Klopfleisch, R., Teifke, J.P. (2004) Studies on the virulence of two field isolates of the classical Swine Fever virus genotype 2.3 rostock in wild boars of different age groups. J Vet Med B Infect Dis Vet Pub Health 51:2028.

Kaltenboeck B, Wang C. Advances in real-time PCR: application to clinical laboratory diagnostics. Adv Clin Chem. 2005;40:219-59. Review.

Kamolsiriprichaiporn, S., Hooper, P.T., Morrissy, C.J., Westbury, H.A. (1992a) A comparison of the pathogenicity of two strains of hog cholera virus. 1. Clinical and pathological studies. Aust Vet J 69:240-4. 
Kamolsiriprichaiporn, S., Morrissy, C.J., Westbury, H.A. (1992b) A comparison of the pathogenicity of two strains of hog cholera virus. 2. Virological studies. Aust Vet J. 69:245-8.

Kant A, Koch G, Van Roozelaar DJ, Balk F, Huurne AT. Differentiation of virulent and non-virulent strains of Newcastle disease virus within 24 hours by polymerase chain reaction. Avian Pathol. 1997 Dec;26(4):837-49.

Katz, J.B., Alstad, A.D., Gustafson, G.A., Moser, K.M., 1993. Sensitive identification of bluetongue virus serogroup by a colorimetric dual oligonucleotide sorbent assay of amplified viral nucleic acid. J. Clin. Microbiol. 31, 3028-3030.

Kho CL, Mohd-Azmi ML, Arshad SS, Yusoff K. Performance of an RT-nested PCR ELISA for detection of Newcastle disease virus. J Virol Methods. 2000 Apr;86(1):7183.

Khripin, Y. (2006) High-throughput genotyping with energy transfer-labeled primers. Methods Mol Biol 335: 215-40.

Kim LM, Afonso CL, Suarez DL. Effect of probe-site mismatches on detection of virulent Newcastle disease viruses using a fusion-gene real-time reverse transcription polymerase chain reaction test. J Vet Diagn Invest. 2006 Nov;18(6):519-28.

Kim LM, King DJ, Curry PE, Suarez DL, Swayne DE, Stallknecht DE, Slemons RD, Pedersen JC, Senne DA, Winker K, Afonso CL. Phylogenetic diversity among lowvirulence newcastle disease viruses from waterfowl and shorebirds and comparison of genotype distributions to those of poultry-origin isolates. J Virol. 2007 81:12641-53

Kim, S.G., Dubovi, E.J. (2003) A novel simple one-step single-tube Rtduplex PCR method with an internal control for detection of bovine viral diarrhoea virus in bulk milk, blood, and follicular fluid samples. Biologicals 31, 103-106.

King, D.P., Reid, S.M., Hutchings, G.H., Grierson, S.S., Wilkinson, P.J., Dixon, L.K., Bastos, A.D., Drew, T.W. (2003) Development of a TaqMan PCR assay with internal amplification control for the detection of African swine fever virus. J Virol Methods. 107(1):53-61

King D. P., Dukes J. P., Reid S. M., Ebert K., Shaw A. E., Mills C. E., Boswell L. and Ferris N. P. (2008) Prospects for rapid diagnosis of foot-and-mouth disease in the field using RT-PCR. Veterinary Record 162 (10): 315-6.

King DP, Ferris NP, Shaw AE, Reid SM, Hutchings GH, Giuffre AC, Robida JM, Callahan JD, Nelson WM, Beckham TR. (2006) Detection of foot-and-mouth disease virus: comparative diagnostic sensitivity of two independent real-time reverse transcription-polymerase chain reaction assays. J Vet Diagn Invest. 18(1):93-7.

King D. P., Montague N., Ebert K., Reid S. M., Dukes J. P., Schädlich L., Belsham G. J., and Lomonossoff G. P. (2007) Development of a novel recombinant encapsidated RNA particle: evaluation as an internal control for diagnostic RT-PCR. Journal of Virological Methods 146: 218-225

\section{Koenig P, Hoffmann B, Depner KR, Reimann I, Teifke JP, Beer M. Detection of} classical swine fever vaccine virus in blood and tissue samples of pigs vaccinated either with a conventional $C$-strain vaccine or a modified live marker vaccine. Vet Microbiol. 2007 Mar 10;120 (3-4):343-51. 
1520 Kompalic-Cristo, A., Frotta, C., Suarez-Mutis, M., Fernandes, O., Britto, C. (2007)

1521 Evaluation of a real-time PCR assay based on the repetitive B1 gene for the detection

1522 of Toxoplasma gondii in human peripheral blood. Parasitol Res Mar 25 (Epub)

1523 Korimbocus, J., Coates, D., Baker, I., Boonham, N., 2002. Improved detection of

1524 sugarcane yellow leaf virus using a real-time fluorescent (TaqMan) RTPCR assay. J.

1525 Virol. Meth. 103, 109-120.

1526 Kou YT, Chueh LL, Wang CH. Restriction fragment length polymorphism analysis of 1527 the F gene of Newcastle disease viruses isolated from chickens and an owl in Taiwan.

1528 Kubista M, Andrade JM, Bengtsson M, Forootan A, Jonák J, Lind K, Sindelka R,

1529 Sjöback R, Sjögreen B, Strömbom L, Ståhlberg A, Zoric N. The real-time polymerase

1530 chain reaction.Mol Aspects Med. 2006 Apr-Jun;27(2-3):95-125. Epub 2006 Feb 3.

1531 Review.

1532 Kusser, W. (2006) Use of self-quenched, fluorogenic LUX primers for gene

1533 expression profiling. Methods Mol Biol 335:115-33.

1534 Kutyavin, I.V., Afonina, I.A., Mills, A., Gorn, V.V., Lukhtanov, E.A., Belousov, E.S., 1535 Singer, M.J., Walburger, D.K., Lokhov, S.G., Gall, A.A., Dempcy, R., Reed, M.W.,

1536 Meyer, R.B., Hedgpeth, J. (2000) 3'-minor groove binder-DNA probes increase

1537 sequence specificity at PCR extension temperatures. Nucleic Acids Res 28(2):655-61.

1538 Latorra, D., Arar, K., Hurley, J.M. (2003) Design considerations and effects of LNA 1539 in PCR primers. Mol Cell Probes 17(5):253-9.

1540 Le Dimna, M., Kuntz-Simon, G., Louguet, Y., Bougeard, S., Le-Potier, M.F. (2006)

1541 Diagnosis validation of new real time RT-PCR kits for detection of classical swine

1542 fever virus. J Recherche Porcine 38:365-70.

1543 Le Dimna M, Vrancken R, Koenen F, Bougeard S, Mesplede A, Hutet E, KuntzSimon G, Le Potier MF. Validation of two commercial real-time RT-PCR kits for rapid and specific diagnosis of classical swine fever virus. J Virol Methods. 2007 Oct 1 .

1548 determination. Anal Biochem 17, 100-107

1549 Lee, C.-W., Suarez, D. L., 2004. Application of real-time RT-PCR for the quantitation 1550 and competitive replication study of $\mathrm{H} 5$ and $\mathrm{H} 7$ subtype avian influenza virus. J.

1551 Virol. Methods 119, 151-158.

1552 Lees, W., Chown, L., Inch, C., Moll, K., Brassel, P., Wu, T., Kahn, S., Pasick, J., 2004. A short summary of the 2004 outbreak of high pathogenicity avian influenza (H7N3) in British Columbia, Canada.

http://www.inspection.gc.ca/english/anima/heasan/disemala/avflu/2004sum/summary hpaie.shtml

1557 Legoff J, Kara R, Moulin F, Si-Mohamed A, Krivine A, Bélec L, Lebon P. Evaluation of the one-step multiplex real-time reverse transcription-PCR ProFlu-1 assay for detection of influenza A and influenza B viruses and respiratory syncytial viruses in children. J Clin Microbiol. 2008 Feb;46(2):789-91.

1561 Leifer, I., Depner, K., Blome, S., Le Potier,M-F., Le Dimna, M., Beer, M. , 1562 Hoffmann, B. 2009. Differentiation of C-strain "Riems" or CP7_E2alf vaccinated 
1563

1564

1565

1566

1567

1568

1569

1570

1571

1572

1573

1574

1575

1576

1577

1578

1579

1580

1581

1582

1583

1584

1585

1586

1587

1588

1589

1590

1591

1592

1593

1594

1595

1596

1597

1598

1599

1600

1601

1602

1603

1604

animals from animals infected by classical swine fever virus field strains using realtime RT-PCR. J. Virol. Meth., in press.

Le Potier, M.F., Le Dimna, M., Kuntz-Simon, G., Bougeard, S., Mesplede, A. (2006) Validation of a real-time RT-PCR assay for rapid and specific diagnosis of Classical Swine Fever virus. Dev Biol.; 126:179-86; discusssion 326-7.

Liu L, Widen F, Baule C, Belak S. A one-step, gel-based RT-PCR assay with comparable performance to real-time RT-PCR for detection of classical swine fever virus.J Virol Methods. 2007 Feb;139(2):203-7.

Liu, J., Xiao, H., Lei, F., Zhu, Q., Qin, K., Zhang, X.-W., Zhang, X.-1., Zhao, D., Wang, G., Feng, Y., Ma, J., Liu, W., Wang, J., Gao, G. F., 2005. Highly pathogenic H5N1 influenza virus infection in migratory birds. Science 309, 1206.

Livak, K.J., Flood, S.J., Marmaro, J., Giusti, W., Deetz, K. (1995) Oligonucleotides with fluorescent dyes at opposite ends provide a quenched probe system useful for detecting PCR product and nucleic acid hybridization. PCR Methods Appl 4(6):35762.

Lockaby SB, Hoerr FJ, Ellis AC, Yu MS. Immunohistochemical detection of Newcastle disease virus in chickens. Avian Dis. 1993 Apr-Jun;37(2):433-7.

Maan S, Maan NS, Ross-Smith N, Batten CA, Shaw AE, Anthony SJ, Samuel AR, Darpel KE, Veronesi E, Oura CA, Singh KP, Nomikou K, Potgieter AC, Attoui H, van Rooij E, van Rijn P, De Clercq K, Vandenbussche F, Zientara S, Bréard E, Sailleau C, Beer M, Hoffman B, Mellor PS, Mertens PP. (2008) Sequence analysis of bluetongue virus serotype 8 from the Netherlands 2006 and comparison to other European strains. Virology 377, 308-318.

Maan, S., Maan, N. S., Samuel, A. R., Rao, S., Attoui, H. \& Mertens, P. P. C. 2007. Analysis and phylogenetic comparisons of full-length VP2 genes of the 24 bluetongue virus serotypes. J. Gen.Virol. 88, 621-630

Mackay IM, Arden KE, Nitsche A.2002. Real-time PCR in virology. Nucleic Acids Res. 30(6):1292-305. Review.

Mackay, I.M. (2004) Real-time PCR in the microbiology laboratory. Clin. Microbiol. Infect. 10, 190-212

MacLachlan, N.J., 1994. The pathogenesis and immunology of bluetongue virus infection of ruminants. Comp. Immunol, Microbiol. Infect. Dis. 17, 197-206.

McGoldrick, A., Bensaude, E., Ibata, G., Sharp, G., Paton, D.J. (1999) Closed onetube reverse transcription nested polymerase chain reaction for the detection of pestiviral RNA with fluorescent probes. J Virol Meth 79:85-95.

Manvell, R.J, Londt, B.Z., Ceeraz, V., Cox, W.J., Essen, S., Banks, J., Slomka, M.J., Pavlidis, T., Irvine, R.M., Wilesmith, J.W., Sharpe, C.E., Hurst, A., Alexander, D.J., Brown, I.H., 2008. Low pathogenic avian influenza in domestic fowl in Norfolk, England, March-April 2006. Vet. Rec. 162, 278-280.

Mellor, P.S., Boorman, J., Baylis, M., 2000. Culicoides biting midges: their role as arbovirus vectors. Annu. Rev. Entemol. 45, 307-340. 
1605

1606

1607

1608

1609

1610

1611

1612

1613

1614

1615

1616

1617

1618

1619

1620

1621

1622

1623

1624

1625

1626

1627

1628

1629

1630

1631

1632

1633

1634

1635

1636

1637

1638

1639

1640

1641

1642

1643

1644

1645

1646

1647
Mertens, P.P., Brown, F., Sangar, D.V., 1984. Assignment of the genome segments of bluetongue virus type 1 to the proteins which they encode.

Virology. 135 (1), 207-17.

Mertens, P.P., Pedley, S., Cowley, J. and Burroughs, J.N., 1987. A comparison of six different bluetongue virus isolates by cross-hybridization of the dsRNA genome segments. Virology 161, 438-47.

Mertens, P.C., Diprose., 2004. The bluetongue virus core: a nano-acale transcription machine. Virus Res. 101, 29-43.

Mertens, P. P. C., Maan, N. S., Prasad, G., Samuel, A. R., Shaw, A. E., A.C., P., Anthony, S. \& Maan, S. 2007. The design of primers and use of RT-PCR assays for typing European BTV isolates: Differentiation of field and vaccine strains. J. Gen. Virol. (in press).

Meyer RF, Brown CC, House C, House JA, Molitor TW (1991) Rapid and sensitive detection of foot-and-mouth disease virus in tissues by enzymatic RNA amplification of the polymerase gene. J. Virol. Methods 34, 161-172.

Meyers G., H. J. Thiel, and T. Rumenapf. 1996. Classical swine fever virus: recovery of infectious viruses from cDNA constructs and generation of recombinant cytopathogenic defective interfering particles. J. Virol. 70:1588-1595.

Mittelholzer, C., Moser, C., Tratschin, J.D., Hofmann, M.A. (2000) Analysis of classical swine fever virus replication kinetics allows differentiation of highly virulent from avirulent strains. Vet Microbiol 74:293-308.

Monne, I., Ormelli, S., Salviato, A., De Battisti, C., Bettini, F., Salomoni, A., Drago, A., Zecchin, B., Capua, I., Cattoli, G., 2008. Development and Validation of a onestep RealTime PCR Assay for simultaneous detection of subtype H5, H7, and H9 avian influenza viruses. J Clin Microbiol 46, 1769-1773.

Moniwa M, Clavijo A, Li M, Collignon B, Kitching PR. (2007) Performance of a foot-and-mouth disease virus reverse transcription-polymerase chain reaction with amplification controls between three real-time instruments J Vet Diagn Invest 19, 920

Moonen P, Boonstra, J, Hakze-van der Honing R, Boonstra-Leendertse C, Jacobs L, Dekker A. (2003) Validation of a LightCycler-based reverse transcription polymerase chain reaction for the detection of foot-and-mouth disease virus. J. Virol. Methods $113,35-41$.

Morrison, T.B., Weis, J.J., Wittwer, C.T. (1998) Quantification of low-copy transcripts by continuous SYBR Green I monitoring during amplification.. Biotechniques 24(6):954-8, 960, 962.

Müller, J., Eis-Hübinger, A.M., Däumer, M., Kaiser, R., Rox, J.M., Gürtler, L., Hanfland, P., Pötzsch, B. (2007) A novel internally controlled real-time reverse transcription-PCR assay for HIV-1 RNA targeting the pol integrase genomic region. $\mathrm{J}$ Virol Methods. Feb 23; (Epub)

Munster, V.J., Wallensten, A., Baas, C., Rimmelzwaan, G.F., Schutten, M., Olsen, B., Osterhaus, A.D., Fouchier, R.A., 2005. Mallards and highly pathogenic avian influenza ancestral viruses, northern Europe. Emerg. Infect. Dis. 11, 1545-1551. 
1648 Munster, V.J., Veen J., Olsen, B.,Vogel, R., Osterhaus, A.D., Fouchier, R.A., 2006.

1649 Towards improved influenza A virus surveillance in migrating birds. Vaccine 24,

$1650 \quad 6729-6733$.

1651 Nazarenko, I.A., Bhatnagar, S.K., Hohman, R.J. (1997) A closed tube format for

1652 amplification and detection of DNA based on energy transfer. Nucleic Acids Res. 25,

$1653 \quad 2516-2521$

1654 Nazarenko, I. (2006) Homogeneous detection of nucleic acids using self-quenched

1655 polymerase chain reaction primers labeled with a single fluorophore (LUX primers).

1656 Methods Mol Biol 335:95-114

1657 Nikolakaki, S.V., Nomikou, K., Koumbati, M., Mangana, O., Papanastassopoulou,

1658 M., Mertens, P.P., Papadopoulos, O., 2005. Molecular analysis of the NS3/NS3A

1659 gene of Bluetongue virus isolates from the 1979 and 1998-2001 epizootics in Greece

1660 and their segregation into two distinct groups. Virus Res. 114(1-2), 6-14.

1661 Niesters HG. Clinical virology in real time. J Clin Virol. 2002 Dec;25 Suppl 3:S3-12.

1662 Review.

1663 Niesters, H.G. (2004) Molecular and diagnostic clinical virology in real time. Clin

1664 Microbiol Infect 10(1):5-11.

1665 Nuovo, G.J., Hohman, R.J., Nardone, G.A., Nazarenko, I.A. (1999) In situ

1666 amplification using universal energy transfer-labeled primers. J. Histochem.

1667 Cytochem. 47, 273-280.

1668 Oem JK, Kye SJ, Lee KN, Kim YJ, Park JY, Park JH, Joo YS, Song HJ. (2005)

1669 Development of a Lightcycler-based reverse transcription polymerase chain reaction

1670 for the detection of foot-and-mouth disease virus. J Vet Sci. 6(3):207-12.

1671 OIE (World Organisation for Animal Health) 2002. OIE Guide 3: Laboratory

1672 Proficiency Testing. In: OIE Quality Standard and Guidelines for Veterinary

1673 Laboratories: Infectious Diseases. OIE, Paris, France, 53-63.

1674 OIE Manual for Diagnostic Tests and Vaccines for Terrestrial Animals 2004. OIE

1675 World Organisation for Animal Health Chapter 2.1.15.

1676 OIE (World Organisation for Animal Health), 2008. Validation and quality control of

1677 polymerase chain reaction methods used for the diagnosis of infectious diseases. In:

1678 Manual of diagnostic tests and vaccines for terrestrial animals. Chapter 1.1.4., 6th ed.

1679 Paris, France. http://www.oie.int/eng/normes/mmanual/A 00014.htm

1680 OIE (World Organisation for Animal Health), 2008. Bluetongue. In: Manual of

1681 Diagnostic Tests and Vaccines for Terrestrial animals, Chapter 2.1.3.

1682 OIE (World Organisation for Animal Health), 2005a. Avian influenza. In: Manual of

1683 diagnostic tests and vaccines for terrestrial animals. Chapter 2.7.12. Paris, France.

1684 http://www.oie.int/eng/normes/mmanual/A_00037.htm

1685 OIE (World Organisation for Animal Health), 2005b. World Health Organisation for

1686 Animal Health, Terrestrial Animal Health Code, $14^{\text {th }}$ chapter 2.7.12.1 on avian

1687 influenza. www.oie.int/eng/normes/moode/en_chapter_2.7.12.htm

1688 OIE. Office International des Epizooties. Diseases notifiable to the OIE; 2006,

$1689 \mathrm{http} / /$ wwwoieint/eng/maladies/en classificationhtm. 
1690 Oleksiewicz, M.B., Donaldson, A.I., Alexandersen, S., 2001. Development of a novel real-time RT-PCR assay for quantitation of foot-and-mouth disease virus in diverse porcine tissues. J. Virol. Meth. 92, 23-35.

1693

1694

1695

1696

1697

1698

1699

1700

1701

1702

1703

1704

1705

1706

1707

1708

1709

1710

1711

1712

1713

1714

1715

1716

1717

1718

1719

1720

1721

1722

1723

1724

1725

1726

1727

1728

1729

1730

1731

1732

1733

Olson, V.A., Laue, T., Laker, M.T., Babkin, I.V., Drosten, C., Shchelkunov, S.N., Niedrig, M., Damon, I.K., Meyer, H. (2004) Real-time PCR system for detection of orthopoxviruses and simultaneous identification of smallpox virus. J Clin Microbiol. 42(5):1940-6

Ophuis RJ, Morrissy CJ, Boyle DB. Detection and quantitative pathogenesis study of classical swine fever virus using a real time RT-PCR assay. J Virol Methods. 2006 Jan;131(1):78-85.

Orru, G., Santis, P.D., Solinas, F., Savini, G., Piras, V. and Caporale, V., 2004. Differentiation of Italian field and South African vaccine strains of bluetongue virus serotype 2 using real-time PCR. J. Virol. Methods 122, 37-43.

Orru, G., Ferrando, M.L., Meloni, M., Liciardi, M., Savini, G., De Santis, Poala., 2006. Rapid detection and quantification of bluetongue virus (BTV) using a Molecular Beacon fluorescent probe assay. J. Virol. Meth. 137, 34-42.

Pasick, J., Robinson, J., Hooper-McGrevy, K., Wright, P., Kitching, P., Handel, K., Copps, J., Ridd, D., Kehler H., Hills, K., Cottam-Birt, C., 2007. The roles of national and provincial diagnostic laboratories in the eradication of highly pathogenic H7N3 avian influenza virus from the Fraser Valley of British Columbia, Canada. Avian Dis. 51, 309-312.

Paton, D.J., McGoldrick, A., Belak, S., Mittelholzer, C., Koenen, F., Vanderhallen, H., Biagetti, M., De Mia, G., Stadejek, T., Hofmann, M.A., Thuer, B. (2000) Classical swine fever virus: a ring test to evaluate RT-PCR detection methods. Vet. Microbiol. 73, 159-174.

Payungporn, S., Chutinimitkul, S., Chaisingh, A., Damrongwantanapokin, S., Buranathai, C., Amonsin, A., Theamboonlers, A., Poovorawan, Y. (2006). Single step multiplex real-time RT-PCR for H5N1 influenza A virus detection. J. Virol. Methods. $131: 143-7$

Persson K, Hamby K, Ugozzoli LA. Four-color multiplex reverse transcription polymerase chain reaction--overcoming its limitations. Anal Biochem. 2005 Sep 1;344(1):33-42.

Pham HM, Konnai S, Usui T, Chang KS, Murata S, Mase M, Ohashi K, Onuma M. Rapid detection and differentiation of Newcastle disease virus by real-time PCR with melting-curve analysis. Arch Virol. 2005 Dec;150(12):2429-38.

Pham HM, Nakajima C, Ohashi K, Onuma M. Loop-mediated isothermal amplification for rapid detection of Newcastle disease virus. J Clin Microbiol. 2005 Apr;43(4):1646-50.

Pierce, C.M., Balasuriya, U.B., Maclachlan, N.J., 1998. Phylogenetic analysis of the S10 gene of field and laboratory strains of bluetongue virus from the United States. Virus Res. 55, 15-27.

Polci, A., Cammà, C, Serini, S., Di Gialleonardo, L., Monaco, F., Savini, G., 2007. Real-time polymerase chain reaction to detect bluetongue virus in blood samples. Vet. Italia. 43 (1), 77-87. 
1734 Purse, B.V., Mellor, P.S., Rogers, D.J., Samuel, A.R., Mertens, P.P. and Baylis, M.,

1735

1736

1737

1738

1739

1740

1741

1742

1743

1744

1745

1746

1747

1748

1749

1750

1751

1752

1753

1754

1755

1756

1757

1758

1759

1760

1761

1762

1763

1764

1765

1766

1767

1768

1769

1770

1771

1772

1773

1774

1775

1776

1777

2005. Climate change and the recent emergence of bluetongue in Europe. Nat Rev Microbiol 3, 171-81.

Rasmussen, T.B., Uttenthal, A., Reimann, I., Nielsen, J., Depner, K., Beer, M. (2007) Virulence, immunogenicity and vaccine properties of a novel chimeric pestivirus. J Gen Virol 88(Pt 2):481-6.

Rasmussen, T.B., Uttenhal, Å., de Stricker, K., Belák, S. and Storgaard, T. (2003). Development of a novel quantitative real-time RT-PCR assay for the simultaneous detection of all serotypes of foot-and-mouth disease virus. Archives of Virology, 148, 2005-2021.

Rasmussen TB, Uttenthal A, Aguero M. (2006) Detection of three porcine vesicular viruses using multiplex real-time primer-probe energy transfer. J Virol Methods 134(1-2):176-82.

Ratcliff RM, Chang G, Kok T, Sloots TP. (2007) Molecular diagnosis of medical viruses. Curr Issues Mol Biol. Jul;9(2):87-102

Reid SM, Hutchings GH, Ferris NP, De Clercq K. (1999) Diagnosis of foot-andmouth disease by RT-PCR: evaluation of primers for serotypic characterisation of viral RNA in clinical samples. J. Virol. Methods 83, 113-123.

Reid SM, Ferris NP, Hutchings GH, Samuel AR, Knowles NJ. (2000) Primary diagnosis of foot-and-mouth disease by reverse transcriptionpolymerase chain reaction. J. Virol. Methods 89, 167-176.

Reid SM, Ferris NP, Hutchings GH, Zhang Z, Belsham GJ, Alexandersen S. (2002)

Detection of all seven serotypes of foot-and-mouth disease virus by real-time, fluorogenic reverse transcription polymerase chain reaction assay $\mathrm{J}$ Virol Methods 105(1):67-80

Reid SM, Grierson SS, Ferris NP, Hutchings GH, Alexandersen S. (2003) Evaluation of automated RT-PCR to accelerate the laboratory diagnosis of foot-and-mouth disease virus J Virol Methods 107(2):129-39

Reid SM, Ferris NP, Hutchings GH, King DP, Alexandersen S. (2004) Evaluation of real-time reverse transcription polymerase chain reaction assays for the detection of swine vesicular disease virus. J Virol Methods. 116(2):169-76.

Reid SM, Parida S, King DP, Hutchings GH, Shaw AE, Ferris NP, Zhang Z, Hillerton JE, Paton DJ. (2006) Utility of automated real-time RT-PCR for the detection of footand-mouth disease virus excreted in milk. Vet Res. 37(1):121-32.

Risatti, G.R., Callahan, J.D., Nelson,W.M., Borca, M.V. (2003) Rapid detection of classical swine fever virus by a portable real-time reverse transcriptase PCR assay. J. Clin. Microbiol. 41, 500-505.

Risatti, G., Holinka, L., Lu, Z., Kutish, G., Callahan, J.D., Nelson, W.M., Brea Tio, E., Borca, M.V. (2005) Diagnostic evaluation of a real-time reverse transcriptase PCR assay for detection of classical swine fever virus. J Clin Microbiol 43(1):468-

Roberts, L. (2000) Human genome research - SNP mappers confront reality and find it daunting. Science 287 (5460): 1898-1899.

Rodríguez A, Núñez JI, Nolasco G, Ponz F, Sobrino F, De Blas C. (1994) Direct PCR detection of foot-and-mouth disease virus. J. Virol. Methods 47, 345-349. 
Rohm, C., Horimoto, T., Kawaoka, Y., Suss, J., Webster, R.G., 1995. Do hemagglutinin genes of highly pathogenic avian influenza viruses constitute unique phylogenetic lineages? Virology 209, 664-670.

Roy, P., 1989. Bluetongue virus genetics and genome structure. Virus Res. 13, 179206.

Roy, P., Marshall, J.J.A., French, T.J., 1990. Structure of Bluetongue virus genome and its encoded proteins. In: Roy, P., Gorman, B.M. (Eds), Current Topics in Microbiology and Immunology. Springer, Berlin.

Sammin DJ, Paton DJ, Parida S, Ferris NP, Hutchings GH, Reid SM, Shaw AE. Holmes C, Gibson D, Corteyn M, Knowles NJ, Valarcher J. -F, Hamblin PA, Fleming L, Gwaze G, Sumption KJ. (2006) Evaluation of laboratory tests for SAT serotypes of foot-and-mouth disease virus with specimens collected from convalescent cattle in Zimbabwe. Vet. Record in press.

Schnyder, M., Stärk, K.D.C., Vanzetti, T., Salman, M.D., Thür, B., Schleiss, W., Griot, C. (2002) Epidemiology and control of an outbreak of classical swine fever in wild boar in Switzerland. Vet. Rec. 150, 102-109

Schweiger, B., Zadow, I., Heckler, R., Timm, H., Pauli, G. (2000) Application of a Fluorogenic PCR Assay for Typing and Subtyping of Influenza Viruses in Respiratory Samples J Clin Microbiol 38 (4), 1552-1558

Selvin, PR., Hearst, J.E. (1994) Luminescence energy transfer using a terbium chelate: improvements on fluorescence energy transfer. Proc Natl Acad Sci 91(21):10024-8.

Senne, D.A., 2007. Avian influenza in North and South America, 2002-2005. Avian Dis. $51,167-173$.

Senne, D.A., Pedersen, J.C., Suarez, D.L., Panigrahy, B., 2006. Rapid diagnosis of avian influenza(AI) and assessment of pathogenicity of avian $\mathrm{H} 5$ and $\mathrm{H} 7$ subtypes by molecular methods. Dev. Biol. 126, 171-177.

Shaw AE, Reid SM, King DP, Hutchings GH, Ferris NP. (2004) Enhanced laboratory diagnosis of foot and mouth disease by real-time polymerase chain reaction. Rev Sci Tech. 23(3):1003-9.

Shaw, A., Monaghan, P., Alpar, H. O., Anthony, S., Darpel, K. E., Batten, C. A., Carpenter, S., Jones, H., Oura, C. A. L., King, D. P., Elliott, H., Mellor, P. S. \& Mertens, P. P. C. (2007). Development and validation of a real-time RT-PCR assay to detect genome bluetongue virus segment 1. J. Virol. Meth. (in press).

Slomka, M., 2006. Ring trial of molecular detection/characterisation methods for avian influenza. In: "Joint Twelfth Annual Meeting of the National Reference Laboratories for Newcastle Disease and Avian Influenza of European Union Member States 2006." http://ec.europa.eu/food/animal/diseases/controlmeasures/avian/docs/jam_nwd_ailc 2 $\underline{006 \text { en.pdf }}$

Slomka, M., 2007. Interlaboratory ring trial of molecular detection / characterisation methods for AI. In: "Joint Thirteenth Annual Meeting of the National Reference Laboratories for Newcastle Disease and Avian Influenza of European Union Member States 2007." 
1822

1823

1824

1825

1826

1827

1828

1829

1830

1831

1832

1833

1834

1835

1836

1837

1838

1839

1840

1841

1842

1843

1844

1845

1846

1847

1848

1849

1850

1851

1852

1853

1854

1855

1856

1857

1858

1859

1860

1861

1862

1863

1864

1865

1866

http://ec.europa.eu/food/animal/diseases/controlmeasures/avian/docs/programme13th 2007.pdf

Slomka, M., 2008. The third pan-European AI PCR Proficiency Panel. In: "Joint Fourteenth Annual Meetings of the National Laboratories for Avian Influenza and Newcastle Disease of European Union Member States 2008."

http://ec.europa.eu/food/animal/diseases/controlmeasures/avian/docs/programme14th 2008.pdf

Slomka, M.J., Voermans, J., 2007. Development and validation of H7 RealTime RTPCR._In: "Joint Thirteenth Annual Meeting of the National Reference Laboratories for Newcastle Disease and Avian Influenza of European Union Member States 2007."

http://ec.europa.eu/food/animal/diseases/controlmeasures/avian/docs/programme13th 2007.pdf

Slomka, M.J, Coward, V.J., Banks, J., Löndt, B.Z., Brown, I.H, Voermans, J., Koch, G., Handberg, K.J., Jørgensen, P.H., Cherbonnel-Pansart, M., Jestin, V., Cattoli, G., Capua, I., Ejdersund, A., Thorén, P., Czifra, G., 2007a. Identification of sensitive and specific avian influenza PCR methods through blind ring trials in the European Union. Avian Dis. 51, 227-234.

Slomka, M. J., Pavlidis, T., Banks, J., Shell, W., McNally, A., Essen, S., Brown, I. H., 2007b. Validated H5 Eurasian real-time reverse transcriptase-polymerase chain reaction and its application in H5N1 outbreaks in 2005-2006. Avian Dis. 51, 373377.

Smith, G.J.D, Fan, X.H, Wang, J., Li, K.S., Qin, K., Zhang, J.X., Vijaykrishna, D., Cheung, C.L., Huang, K., Rayner, J.M., Peiris, J.S.M., Chen, H., Webster, R.G., Guan, Y., 2006. Emergence and predominance of an H5N1 influenza variant in China. Proc. Natl. Acad. Sci. U S A 103, 16936-16941.

Spackman, E., Senne, D. A., Myers, T. J., Bulaga, L. L., Garber, L. P., Perdue, M. L., Lohman, K., Daum, L. T., Suarez, D. L., 2002. Development of a real-time reverse transcriptase PCR assay for type A influenza virus and the avian $\mathrm{H} 5$ and $\mathrm{H} 7$ haemagglutinin subtypes. J. Clin. Microbiol. 40, 3256-3260.

Stranska, R., Schuurman, R., de Vos, M., van Loon, A.M. (2004) Routine use of a highly automated and internally controlled real-time PCR assay for the diagnosis of herpes simplex and varicella-zoster virus infections. J. Clin. Virol. 30, 39-44.

Suarez, D.L., Das, A., Ellis, E., 2007. Review of rapid molecular diagnostic tools for avian influenza virus. Avian Dis. 51, 201-208.

Swayne, D.E, Akey, B.L, 2005. Avian influenza control strategies in the United States of America. In: “Avian Influenza: Prevention and Control”, eds: Shrijver, R.S, Koch, G., pp113-130, Springer.

Swayne, D. E., Suarez, D. L., 2000. Highly pathogenic avian influenza. Rev. Sci. Tech. 19, 463-482.

Tan SW, Omar AR, Aini I, Yusoff K, Tan WS. Detection of Newcastle disease virus using a SYBR Green I real time polymerase chain reaction. Acta Virol. 2004;48(1):23-8.

Terregino, C., De Nardi, R., Guberti, V., Scremin, M., Raffini, E., Martin, A.M., Cattoli, G., Bonfanti, L., Capua, I., 2007. Active surveillance for avian influenza 
1867

1868

1869

1870

1871

1872

1873

1874

1875

1876

1877

1878

1879

1880

1881

1882

1883

1884

1885

1886

1887

1888

1889

1890

1891

1892

1893

1894

1895

1896

1897

1898

1899

1900

1901

1902

1903

1904

1905

1906

1907

1908

1909

1910

viruses in wild birds and backyard flocks in Northern Italy during 2004 to 2006. Avian Path. 36, 337-344.

Thelwell, N., Millington, S., Solinas, A., Booth, J., Brown, T. (2000) Mode of action and application of Scorpion primers to mutation detection. Nucleic Acids Res 28(19):3752-61.

Toussaint, J.F., Sailleau, C., Breard, E., Zientara, S., De Clercq, K. (2007) Bluetongue virus detection by two real-time RT-qPCRs targeting two different genomic segments. J Virol Methods. 140(1-2):115-23.

Tsai HJ, Chang KH, Tseng CH, Frost KM, Manvell RJ, Alexander DJ. Antigenic and genotypical characterization of Newcastle disease viruses isolated in Taiwan between 1969 and 1996. Vet Microbiol. 2004 Nov 30;104(1-2):19-30.

Tseng, S.Y., Macool, D., Elliott, V., Tice, G., Jackson, R., Barbour, M., Amorese, D. (1997) An homogeneous fluorescence polymerase chain reaction assay to identify Salmonella. Anal Biochem 245(2):207-12.

Tyagi, S., Kramer, F.R. (1996) Molecular beacons: probes that fluoresce upon hybridization. Nat Biotechnol 14(3):303-8.

Tyagi, S., Bratu, D.P., Kramer, F.R. (1998) Multicolor molecular beacons for allele discrimination. Nat Biotechnol 16(1):49-53.

Uttenthal, A., Storgaard, T., Oleksiewicz, M.B., de Stricker, K., 2003. Experimental infection with the Paderborn isolate of classical swine fever virus in 10-week-old pigs: determination of viral replication kinetics by quantitative RT-PCR, virus isolation and antigen ELISA. Vet. Microbiol. 92, 197-212.

Van Borm, S., Steensels, M., Ferreira, H.L, Boschmans, M., De Vriese, J., Lambrecht, B., van den Berg, T., 2007. A universal avian endogenous Real-Time reverse transcriptase-polymerase chain reaction control and its application to avian influenza diagnosis and quantification. Avian Dis. 51, 213-220.

Vangrysperre W, De Clercq K (1996) Rapid and sensitive polymerase chain reaction based detection and typing of foot-and-mouth disease virus in clinical samples and cell culture isolates, combined with a simultaneous differentiation with other genomically and/or symptomatically related viruses. Arch. Virol. 141, 331-344.

Van Niekerk, M., Freeman, M., Paweska, J.T., Howell, P.G., Guthrie, A.J., Potgieter, A.C., van Staden, V., Huismans, H., 2003. Variation in the NS3 gene and protein in South African isolates of bluetongue and equine encephalosis viruses. J. Gen. Virol. 84 (Pt 3), 581-90.

Vet, J.A., Van der Rijt, B.J., Blom, H.J. (2002) Molecular beacons: colorful analysis of nucleic acids. Expert Rev Mol Diagn 2(1):77-86.

Vilcek, S., Herring, A.J., Nettleton, P.F., Lowings, J.P., Paton, D.J. (1994)

Pestiviruses isolated from pigs, cattle and sheep can be allocated into at least three genogroups using polymerase chain reaction and restriction endonuclease analysis. Arch Virol 136:309-23.

Walton, T.E., 2004. The history of bluetongue and a current global overview. Vet. Ital. 40, 31-38.

Wengler, G., D. W. Bradley, M. S. Colett, F. X. Heinz, R. W. Schlesinger, and J. H. Strauss. 1995. Flaviviridae, p. 415-427. In F. A. Murphy, C. M. Fauquet, D. H. L. 
1911 Bishop, S. A. Ghabrial, A. W. Jarbis, G. P. Martelli, M. A. Mayo, and M. D. Summers

1912 (ed.), Virus taxonomy. Sixth Report of the International Committee on Taxonomy of

1913 Viruses. Springer-Verlag, New York, N.Y.

1914 Wallensten, A., Munster, V.J., Latorre-Margalef, N., Brytting, M., Elmberg, J.,

1915 Fouchier, R.A., Fransson, T., Haemig, P.D., Karlsson, M., Lundkvist, A., Osterhaus,

1916 A.D., Stervander, M., Waldenström, J., Björn, O., 2007. Surveillance of influenza A

1917 virus in migratory waterfowl in northern Europe. Emerg. Infect. Dis. 13, 404-411.

1918 Webster, R.G., Peiris, M., Chen, H., Guan, Y., 2006. H5N1 outbreaks and enzootic

1919 influenza. Emerging Inf. Dis. 12, 3-8.

1920 West, D.M., Sprigings, K.A-, Cassar, C., Wakeley, P.R., Sawyer, J., Davies, R.H.

1921 (2007) Rapid detection of Escherichia coli virulence factor genes using multiplex real-

1922 time TaqMan((R)) PCR assays. Vet Microbiol. Feb 4; (Epub)

1923 Wilson, W.C., Stallknecht, D.E., Mecham, J.O., 2004. Field-deployable real-time

1924 polymerase chain reaction detection of bluetongue and epizootic haemorrhagic

1925 disease viral ribonucleic acid. Vet. Ital. 40 (4), 587-593.

1926 Wirz, B., J.-D. Tratchin, H. K. Muller, and D. B. Mitchell. 1993. Detection of hog

1927 cholera virus and differentiation from other pestiviruses by polymerase chain reaction.

1928 J. Clin. Microbiol. 31:1148-1154.

1929 Wittwer, C.T., Herrmann, M.G., Gundry, C.N., Elenitoba-Johnson, K.S. (2001) Real-

1930 time multiplex PCR assays. Methods 25, 430-442

1931 Wittwer, C.T., Herrmann, M.G, Moss, A.A., Rasmussen, R.P. (1997a) Continuous

1932 fluorescence monitoring of rapid cycle DNA amplification. Biotechniques. 22(1):130-

1933 1, 134-8.

1934 Wittwer, C.T., Ririe, K.M., Andrew, R.V., David, D.A., Gundry, R.A., Balis, U.J.

1935 (1997b) The LightCycler: a microvolume multisample fluorimeter with rapid

1936 temperature control. Biotechniques 22(1):176-81.

1937 WHO (World Health Organization) Global Influenza Program Surveillance Network, 1938 2005. Evolution of H5N1 avian influenza viruses in Asia. Emerg Infect Dis. 11,1515193921.

1940 Whitcombe, D., Theaker, J., Guy, S.P., Brown, T., Little, S. (1999) Detection of PCR 1941 products using self-probing amplicons and fluorescence. Nat Biotechnol 17(8):804-7.

1942 Wise MG, Suarez DL, Seal BS, Pedersen JC, Senne DA, King DJ, Kapczynski DR, 1943 Spackman E. Development of a real-time reverse-transcription PCR for detection of newcastle disease virus RNA in clinical samples. J Clin Microbiol. 2004 Jan;42(1):329-38.

Wood, G. W., Parsons, G., Alexander, D. J., 1995. Replication of influenza A viruses of high and low pathogenicity for chickens at different sites in chickens and ducks following intranasal inoculation. Avian Pathol. 24, 545-551.

1949 Wu, C., Cheng, X., He, J., Lv, X., Wang, J., Deng, R., Long, Q., Wang, X. (2008). A 1950 multiplex real-time RT-PCR for detection and identification of influenza virus types 1951 A and B and subtypes H5 and N1. J. Virol. Methods. 148:81-8

1952 Wu, P., Brand, L. (1994) Resonance energy transfer: methods and applications. Anal 1953 Biochem 218(1):1-13 
1954 Zhao JJ, Cheng D, Li N, Sun Y, Shi Z, Zhu QH, Tu C, Tong GZ, Qiu HJ.Evaluation 1955 of a multiplex real-time RT-PCR for quantitative and differential detection of wild1956 type viruses and C-strain vaccine of Classical swine fever virus. Vet Microbiol. 2008 1957 Jan 1; 126(1-3):1-10.

1958 Zou J, Shan S, Yao N, Gong Z. Complete genome sequence and biological 1959 characterizations of a novel goose paramyxovirus-SF02 isolated in China. Virus 1960 Genes. 2005 Jan;30(1):13-21.

1961 Zientara, S., Breard, E., Sailleau, C., 2004. Bluetongue diagnosis by reverse 1962 transcriptase-polymerase chain reaction. Vet. Ital, 40 (4), 531-537.

1963

1964 


\section{Figure legends}

1966

1967 Figure 1: Location of pan-serotype rRT-PCR targets within the 5' UTR (untranslated

1968 region) and 3D (RNA polymerase) genes of the FMDV genome. Boxes represent sites 1969 recognised by the primers and probes for the respective assays with * denoting the 1970 location of redundant bases which have been incorporated into the design of primers

1971 to accommodate mismatches. The bar-plots show corresponding variability at each 1972 nucleotide position assessed from analysis of 122 full genomic sequences of FMDV. 1973

1974 Figure 2: Diagram showing relative positions of AI PCR amplicons within different 1975 AIV ORFs. rRT PCR amplicons are shown as unbroken horizontal lines for: (1) M 1976 gene: a (99 bp size, Spackman et al 2002) and b (147bp, Di Trani et al 2006). (2) H5:

1977 c (ca 120-150bp, depending on precise CS size, Hoffmann et al 2007), d (152bp, 1978 Spackman et al 2002 and Slomka et al 2007b) and e (61bp, Monne et al 2008). (3)

1979 H7: f (ca 270-290bp) and g (132bp), both Slomka \& Voermans (2007); h (98bp, 1980 Spackman et al 2002) and i (62bp, Monne et al 2008). Conventional PCR amplicons 1981 assessed by Slomka et al (2007a) are shown as broken horizontal lines and indicated 1982 by italic letters for: (2) H5: j (ca 300-330bp, KHA primers) and k (ca 300-330bp, 1983 J3/B2a primers). (3) H7: 1 ( ca 200-230bp, GK primers).

1984

1985

1986

1987

1988

1989

1990

1991

1992

1993 
Table 1: Published real-time RT-PCR assays for the pan-serotype detection of FMDV

\begin{tabular}{|c|c|c|c|c|}
\hline Forward primer $\left(5^{\prime}-3^{\prime}\right)$ & Reverse primer $\left(5^{\prime}-3^{\prime}\right)$ & Probe $\left(5^{\prime}-3^{\prime}\right)$ & $\begin{array}{c}\text { Genomic } \\
\text { target }\end{array}$ & Reference \\
\hline $\begin{array}{l}\text { CACYTYAAGRTGACAYTGRTACT } \\
\text { GGTAC }\end{array}$ & CAGATYCCRAGTGWCICITGTTA & CCTCGGGGTACCTGAAGGGCATCC & IRES & Reid et al., 2002 \\
\hline TGTGTGCAACCCCAGCAC & CGAGTGTCGCRTGTTACC & $\begin{array}{l}\text { ACAGGCTAAGGATGCCCTTCAGGT } \\
\text { ACC }\end{array}$ & IRES & Oem et al., 2005 \\
\hline AACACGCYGTSTTYGCSTG & GCGTCCAKGGGTARAAGTC & ACCTCCAACGGGTGGTACGCGAT & Leader & Oem et al., 2005 \\
\hline \multicolumn{5}{|c|}{ Alternative pan-reactive fluorogenic rRT-PCR formats } \\
\hline \multirow[t]{2}{*}{ TGGGTTTTACAAACCTGTGATG } & CGCAGGTAAAGTGATCTGTAGC & $\underset{\mathrm{b}}{\mathrm{TCTCCTGTATGGTCCCACGGCGTG}}$ & $3 \mathrm{D}$ & Moonen et al., 2003 \\
\hline & & $\underset{\mathrm{b}}{\text { GCGAGTCCTGCCACGGAGATCAAC }}$ & & \\
\hline GACAAAGGTTTTGTTCTTGGTCA & TGCGAGTCCTGCCACGGA & $\begin{array}{l}\text { ATCCTCTCCTTTGCACGCCGTGGG } \\
\text { ACCAT }\end{array}$ & $3 \mathrm{D}$ & Rasmussen et al., $2003^{c}$ \\
\hline
\end{tabular}

${ }^{\text {a }}$ Minor groove binder probe $(\mathrm{MGB})$

${ }^{\mathrm{b}}$ Dual hybridisation probes

${ }^{\mathrm{c}}$ Primer probe-energy transfer (PriProET) assay: reverse primer is labelled at the 5' end with FAM and the probe is labelled at the 3' end with CY5 
Table 2: Published real-time RT-PCR assays used for detection of CSFV genome

\begin{tabular}{|c|c|c|c|c|c|}
\hline Literature & $\begin{array}{l}\text { Primer/probe } \\
\text { name }\end{array}$ & Sequence 5' $\rightarrow$ 3' & $\begin{array}{l}\text { Genome } \\
\text { position }^{\text {a }}\end{array}$ & $\begin{array}{l}\text { fragment } \\
\text { size }\end{array}$ & \begin{tabular}{|l|} 
internal \\
control
\end{tabular} \\
\hline $\begin{array}{l}\text { Hoffmann et al., } 2005 \\
\text { Depner et al., } 2006\end{array}$ & $\begin{array}{l}\text { CSF 100-F } \\
\text { CSF 192-R } \\
\text { CSF-Probe 1 }\end{array}$ & $\begin{array}{l}\text { ATG CCC AYA GTA GGA CTA GCA } \\
\text { CTA CTG ACG ACT GTC CTG TAC } \\
\text { FAM-TGG CGA GCT CCC TGG GTG GTC TAA GT-TAMRA }\end{array}$ & $\begin{array}{l}100-120 \\
192-172 \\
141-166\end{array}$ & $93 \mathrm{bp}$ & $\begin{array}{l}\text { in vitro- } \\
\text { transcribed } \\
\text { EGFP-RNA }\end{array}$ \\
\hline $\begin{array}{l}\text { Risatti et al., } 2003 \\
\text { Deng et al., } 2005 \\
\text { Ophuis et al., } 2006\end{array}$ & $\begin{array}{l}\text { forward } \\
\text { reverse } \\
\text { probe }\end{array}$ & $\begin{array}{l}\text { CCCTGGGTGGTCTAAG } \\
\text { CATGCCCTCGTCCAC } \\
\text { FAM-CCTGAGTACAGGACAGTCGTCAGTAGTT-TAMRA } \\
\end{array}$ & $\begin{array}{l}150-165 \\
242-228 \\
167-194\end{array}$ & $93 \mathrm{bp}$ & $\begin{array}{l}\text { no internal } \\
\text { control } \\
18 \mathrm{~s} \text { rRNA }\end{array}$ \\
\hline $\begin{array}{l}\text { McGoldrick et al., } 1998 \\
\text { Vilcek et al., } 1994\end{array}$ & $\begin{array}{l}\text { V324 forward } \\
\text { V326 reverse } \\
\text { A11-forward } \\
\text { A14-reverse } \\
\text { probe }\end{array}$ & $\begin{array}{l}\text { 1. Panpesti RT-PCR: } \\
\text { ATG CCC ATA GTA GGA CTA GCA } \\
\text { TCA ACT CCA TGT GCC ATG TAC } \\
\text { 2. CSFV specific fluorogenic nested PCR: } \\
\text { AGT ACA GGG TAG TCG TCA GTG GTT CG } \\
\text { CTG CTG TAC ATG GCA CAT GGA GTT G } \\
\text { FAM-TGA TGG GGG TAC GAC CTG ATA GGG T-TAMRA }\end{array}$ & $\begin{array}{l}100-120 \\
383-363 \\
171-196 \\
382-358 \\
296-320 \\
\end{array}$ & $284 \mathrm{bp}$ & $\begin{array}{l}\text { no internal } \\
\text { control }\end{array}$ \\
\hline $\begin{array}{l}\text { Rassmussen et al., } 2007 \\
\text { Uttenthal et al., } 2003\end{array}$ & $\begin{array}{l}\text { CSFV6 forward } \\
\text { CSFV7 reverse } \\
\text { probe }\end{array}$ & $\begin{array}{l}\text { CTA GCC ATG CCC IYA GTA GGA } \\
\text { CTC CAT GTG CCA TGT ACA GCA } \\
\text { FAM-CCC TGG GTG GTC TAA GTC CTG AGT ACA G-TAMRA }\end{array}$ & \begin{tabular}{|l|}
$94-114$ \\
$379-359$ \\
$150-177$
\end{tabular} & $286 \mathrm{bp}$ & $\begin{array}{l}\text { no internal } \\
\text { control }\end{array}$ \\
\hline $\begin{array}{l}\text { Le Potier et al., 2006; } \\
\text { Le Dimna et al., } 2006\end{array}$ & not stated & $\begin{array}{l}\text { not stated, commercially available kits: } \\
\text { TaqVet CSF (LSI), Adiavet CSF (ADIAGENE) }\end{array}$ & not stated & not stated & $\begin{array}{l}\text { housekeeping } \\
\text { gene: GAPDH }\end{array}$ \\
\hline $\begin{array}{l}\text { Jamnikar Ciglenečki et } \\
\text { al., } 2008\end{array}$ & $\begin{array}{l}\text { CSFV primer B-L } \\
\text { CSFV primer C-U } \\
\text { CSFV-Probe }\end{array}$ & $\begin{array}{l}\text { GGA CAG TCG TCA GTA GTT CG } \\
\text { CTG CAG CAC CCT ATC AGG TC } \\
F A M-C A G \text { GTC GTA CYC CCA TCA-MGB } \\
\end{array}$ & \begin{tabular}{|l|}
$177-196$ \\
$327-308$ \\
$313-296$ \\
\end{tabular} & $151 \mathrm{bp}$ & $\begin{array}{l}\text { no internal } \\
\text { control }\end{array}$ \\
\hline Liu et al. 2007 & $\begin{array}{l}\text { CSF145F CSF242R } \\
\text { TaqMan probe }\end{array}$ & $\begin{array}{l}\text { GAG CTC CCT GGG TGG TCT AAG T } \\
\text { CAT GCC CTC GTC CAC RTA GC } \\
F A M-A C G \text { TCG AAC TAC TGA CGA CTG TCC TGT ACT CA-BHQ1 }\end{array}$ & \begin{tabular}{|l|}
$145-166$ \\
$242-223$ \\
$200-169$ \\
\end{tabular} & $98 \mathrm{bp}$ & $\begin{array}{l}\text { no internal } \\
\text { control }\end{array}$ \\
\hline Zhao et al. 2008 & $\begin{array}{l}\text { CSFV-F } \\
\text { CSFV-R } \\
\text { FAM-CSFV-v111 } \\
\text { TET-CSFV-a110 } \\
\end{array}$ & $\begin{array}{l}\text { GAA CTG GGC TAG CCA TG } \\
\text { ACT GTC CTG TAC TCA GGA C } \\
F A M-A G G \text { ACT AGC AAA CGG AGG GAC TAG CCG-TAMRA } \\
\text { TET-TAG GAC TAG CAA AAC GGA GGG ACT AGC CA-TAMRA }\end{array}$ & \begin{tabular}{|l|}
$86-102$ \\
$183-164$ \\
$111-137$ \\
$110-138^{b}$
\end{tabular} & $\begin{array}{l}98 \text { bp } \\
\text { (99 bp for } \\
\text { 'Chinese' } \\
\text { C strain) }\end{array}$ & $\begin{array}{l}\text { no internal } \\
\text { control }\end{array}$ \\
\hline
\end{tabular}

${ }^{a}$ Genome position according to CSFV Alfort/ 187 (Accession No.: X87939).

$2004{ }^{\mathrm{b}}$ Genome position according to CSFV 'Chinese' C strain (Accession No.: Z46258). 
2006 Table 3: Published real-time RT-PCR assays for the detection of bluetongue virus

\begin{tabular}{|c|c|c|c|}
\hline PCR Target & Detection method & Reference & Strain Identification \\
\hline $\begin{array}{l}\text { BTV Segment } 1 \\
\text { (VP1) }\end{array}$ & duplex RT-PCR & Shaw et al., 2007 & $\begin{array}{l}\text { Representatives from all } 24 \text { serotypes, and } \\
\text { multiple field strains/topotypes. Able to } \\
\text { differentiate between 'eastern' and } \\
\text { 'western' strains of BTV. }\end{array}$ \\
\hline $\begin{array}{l}\text { BTV-Segment } 1 \\
\text { (VP1) }\end{array}$ & One step RT-PCR & Toussaint et al., 2007 & $\begin{array}{l}\text { Representatives from all } 24 \text { serotypes and } \\
\text { field strains from Mediterranean basin. }\end{array}$ \\
\hline $\begin{array}{l}\text { BTV Segment } 5 \\
\text { (NS1) }\end{array}$ & Two step RT-PCR & Toussaint et al., 2007 & $\begin{array}{l}\text { Representatives from all } 24 \text { serotypes and } \\
\text { field strains from Mediterranean basin. }\end{array}$ \\
\hline $\begin{array}{l}\text { BTV Segment } 5 \\
\text { (NS1) }\end{array}$ & One step RT-PCR & Polci et al., 2007 & $\begin{array}{l}\text { Representative from serotypes } 2,4,9 \text { and } \\
16 \text { isolated in Italy and their respective } \\
\text { vaccine strains. }\end{array}$ \\
\hline $\begin{array}{l}\text { BTV Segment } 5 \\
\text { (NS1) }\end{array}$ & One step RT- PCR & $\begin{array}{l}\text { Jiminez-Clavero et } \\
\text { al., } 2006\end{array}$ & $\begin{array}{l}\text { Representatives from } 17 \text { serotypes (BTV } \\
-1,2,3,4,5,6,8,9,11,12,14,15,16, \\
17,18,22,23)\end{array}$ \\
\hline $\begin{array}{l}\text { BTV Segment } 5 \\
\text { (NS1) }\end{array}$ & One step RT-PCR & Wilson et al., 2004 & $\begin{array}{l}\text { Representatives from } 11 \text { serotypes (BTV- } \\
1,5,6,7,8,10,11,13,17,18,19)\end{array}$ \\
\hline $\begin{array}{l}\text { BTV Segment } 10 \\
(\mathrm{NS} 3)\end{array}$ & $\begin{array}{l}\text { MB fluorescent } \\
\text { probe }\end{array}$ & Orrù et al., 2006 & $\begin{array}{l}\text { Representatives from } 10 \text { serotypes (BTV- } \\
1,2,3,4,5,6,7,8,9,16)\end{array}$ \\
\hline $\begin{array}{l}\text { BTV Segment } 2 \\
\text { (VP2) }\end{array}$ & FRET RT-PCR & $\begin{array}{l}\text { De Santis et al., } 2004 \\
\text { Orrù et al., } 2004 .\end{array}$ & $\begin{array}{l}\text { Differentiates field and vaccine strain of } \\
\text { BTV-2 }\end{array}$ \\
\hline
\end{tabular}

2007 MB - Molecular Beacon

2008 FRET - Fluorescence Resonance Energy Transfer 
2010 Table 4: Published real-time RT-PCR assays used for detection of NDV genome

\begin{tabular}{|c|c|c|c|c|}
\hline Literature & Primer/probe name & Sequence $5^{\prime} \rightarrow 3^{\prime}$ & fragment size & target \\
\hline Aldous et al., 2001 & $\begin{array}{l}\text { taqmsfl } \\
\text { not stated } \\
\text { D } \\
1 \mathrm{~V} \\
3 \mathrm{~A} \\
9 \mathrm{~V} \\
10 \mathrm{~V} \\
11 \mathrm{~V} \\
12 \mathrm{~A}\end{array}$ & $\begin{array}{l}\text { GACCGCTGACCACGAGGTTA } \\
\text { CGCAGCATTCTGGTTGGCTTGTATCA } \\
\text { GGCAGCATTTTGTTGGCTTGTATC } \\
\text { FAM-AAGCGTTTCTGTCTCCTTCCTCCG-TAMRA } \\
\text { FAM-AGACGTCCCTGTTTCCCTCCTCC-TAMRA } \\
\text { FAM-AAACGTTTCTGTCTCCTTCCTCCGG-TAMRA } \\
\text { FAM-AAACGTCTCTGTCTCCTTCCTCCGG-TAMRA } \\
\text { FAM-AAGCGTTTCTGCCTCCCTCCTCC-TAMRA } \\
\text { FAM-CCTATAAGGCGCCCCTGTCTCCC-TAMRA }\end{array}$ & not stated & Fusion gene \\
\hline Wise et al., 2004 & $\begin{array}{l}M+4100 \\
M+6169 \\
M-4220\end{array}$ & $\begin{array}{l}\text { AGTGATGTGCTCGGACCTTC } \\
\text { FAM-TTCTCTAGCAGTGGGACAGCCTGC-TAMRA } \\
\text { CCTGAGGAGAGGCATTTGCTA }\end{array}$ & $121 \mathrm{bp}$ & Matrix gene \\
\hline Wise et al., 2004 & $\begin{array}{l}\mathrm{F}+4839 \\
\mathrm{~F}+4894 \\
\mathrm{~F}-4939\end{array}$ & $\begin{array}{l}\text { TCCGGAGGATACAAGGGTCT } \\
\text { FAM-AAGCGTTTCTGTCTCCTTCCTCCA-TAMRA } \\
\text { AGCTGTTGCAACCCAAG }\end{array}$ & $101 \mathrm{bp}$ & $\begin{array}{l}\text { Fusion gene } \\
\text { (velo \& meso) }\end{array}$ \\
\hline Wise et al., 2004 & $\begin{array}{l}M+4213 \\
M-4268 \\
M-4350\end{array}$ & $\begin{array}{l}\text { TCCTCAGGTGGCCAAGATAC } \\
\text { FAM-TTTTAACGCTCCGCAGGCAC-TAMRA } \\
\text { TGCCCCTTCTCCAGCTTAGT }\end{array}$ & $138 \mathrm{bp}$ & $\begin{array}{l}\text { Matrix gene } \\
\text { (pre-1960) }\end{array}$ \\
\hline Kim et al., 2005/2007 & $\begin{array}{l}\text { L-8784 } \\
\text { L-8868 } \\
\mathrm{L}+8817\end{array}$ & $\begin{array}{l}\text { CGTTCTGAGGAATTTGACAGYMT } \\
\text { GRAGCCATGCGAAYTTGG } \\
\text { FAM-CCGGCATTCTGTTTCACTCAA-3BHQ } 1\end{array}$ & $85 \mathrm{bp}$ & L-gene \\
\hline
\end{tabular}




\section{Figure 1}
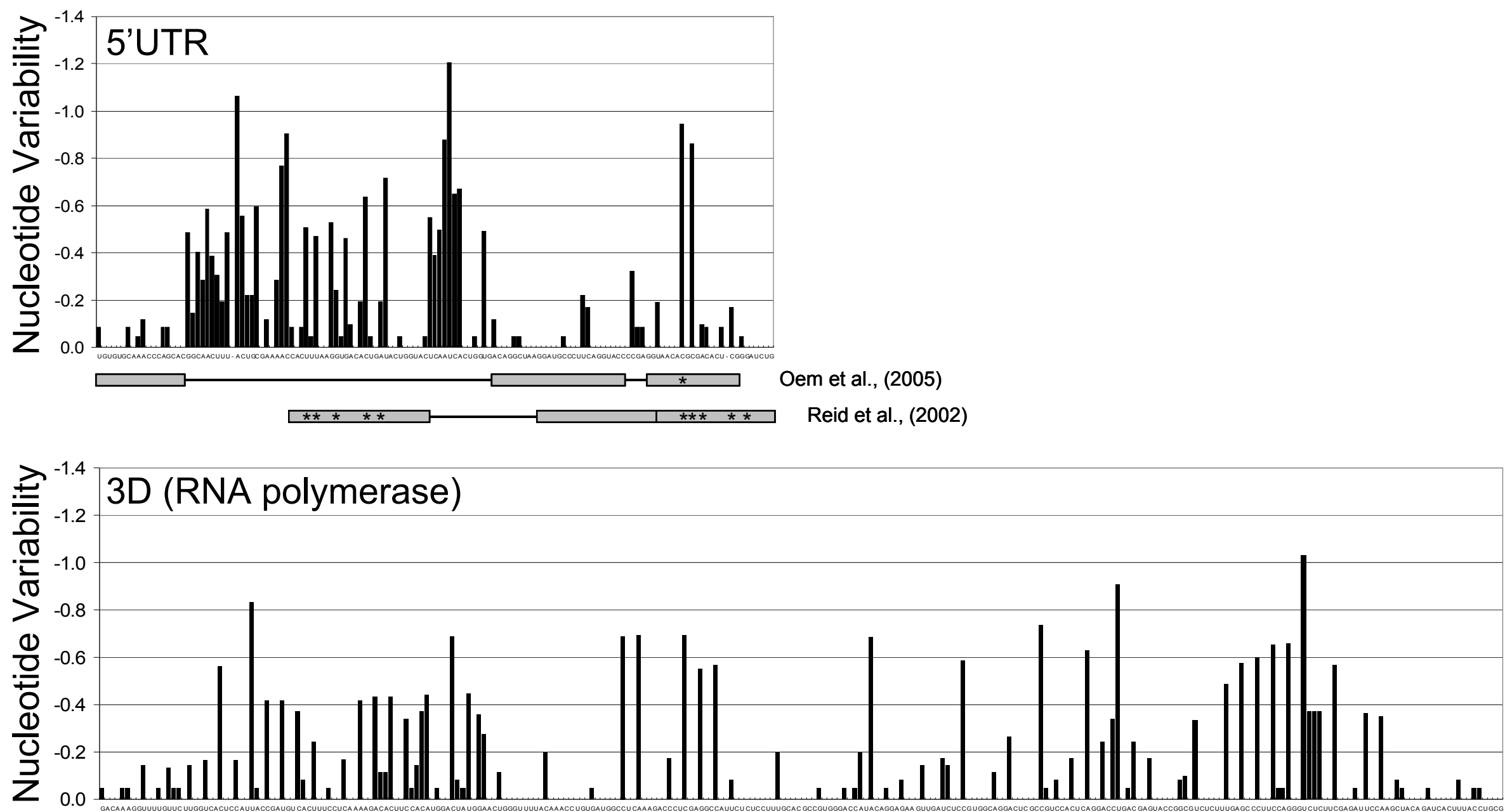

Moniwa et al., (2007)

Moonen et al., (2003)
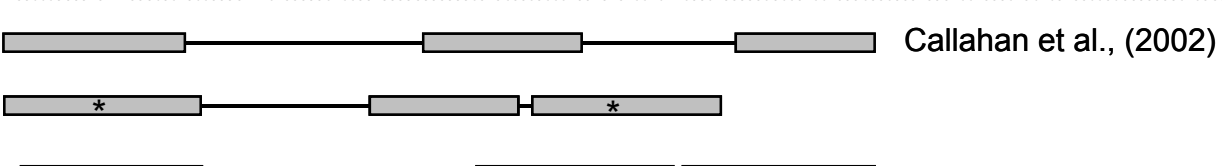

Rasmussen et al., (2003) 


\section{Figure 2}

1) M ORF ca 750 ntds, segment 7 :

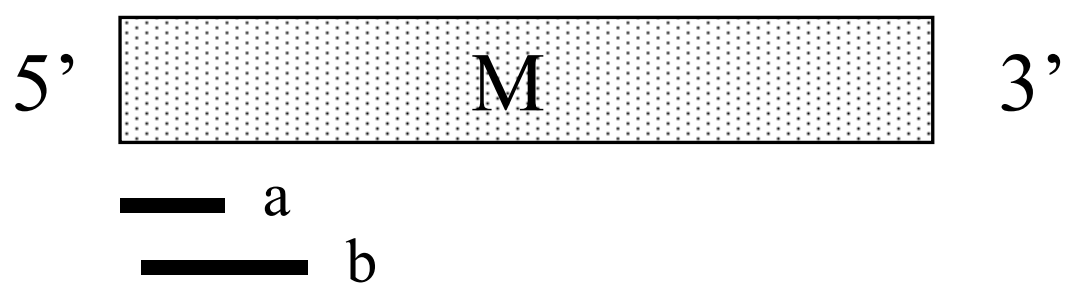

2) H5 ORF (HA0) ca 1700 ntds, segment 4 :

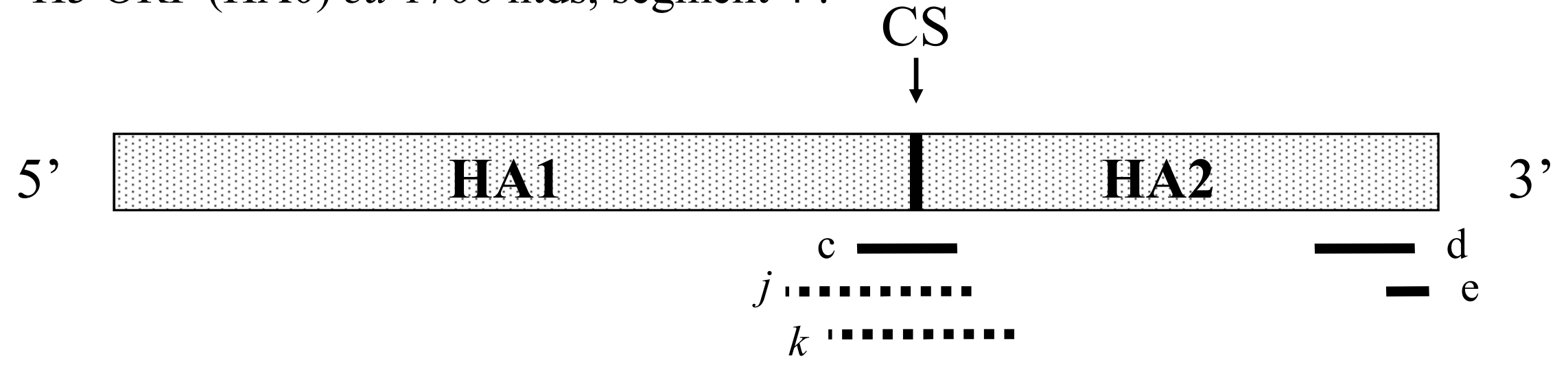

3) H7 ORF (HA0) ca 1700 ntds, segment 4 :

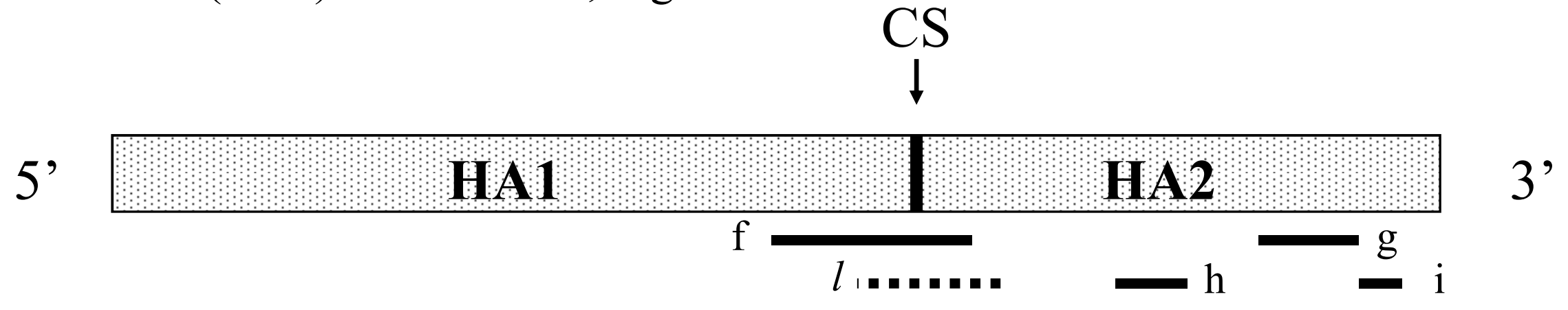

